RODRIGO RAMINA DE LUCCA

DISPONIBILIDADE PROCESSUAL:

OS INTERESSES PRIVADOS DAS PARTES DIANTE DA NATUREZA PÚBLICA DO PROCESSO

TESE DE DOUTORADO

ORIENTADOR: PROFESSOR TITULAR FLÁVIO LUIZ YARSHELL

UNIVERSIDADE DE SÃO PAULO

FACULDADE DE DIREITO

São Paulo - SP

2018 


\title{
OS INTERESSES PRIVADOS DAS PARTES DIANTE DA NATUREZA PÚBLICA DO PROCESSO
}

\begin{abstract}
Tese apresentada a Banca Examinadora do Programa da Pós-Graduação em Direito, da Faculdade de Direito da Universidade de São Paulo, como exigência parcial para obtenção do título de Doutor em Direito, na área de concentração Direito Processual, sob a orientação do Professor Titular Flávio Luiz Yarshell.
\end{abstract}

UNIVERSIDADE DE SÃO PAULO

FACULDADE DE DIREITO

São Paulo - SP 
RODRIGO RAMINA DE LUCCA

\section{A DISPONIBILIDADE PROCESSUAL: OS INTERESSES PRIVADOS DAS PARTES DIANTE DA NATUREZA PÚBLICA DO PROCESSO}

Tese aprovada como requisito parcial para a obtenção do grau de Doutor em Direito Processual Civil no Programa de Pós-Graduação Strictu Sensu da Faculdade de Direito da Universidade de São Paulo, pela seguinte Banca Examinadora:

Orientador: $\quad$ Professor Titular Flávio Luiz Yarshell

Membros: $\quad$ Prof.

Prof.

Prof.

Prof.

Prof.

São Paulo, de de 2018. 


\section{RESUMO}

RAMINA DE LUCCA, Rodrigo. A Disponibilidade Processual: os interesses privados das partes diante da natureza pública do processo. Tese de Doutorado. Faculdade de Direito. Universidade de São Paulo, 2018.

Este trabalho propõe duas teses. A primeira tese é que existem no Direito Processual Civil brasileiro diversas hipóteses de disponibilidade processual e procedimental que não são estudadas e enfrentadas de forma sistemática, embora decorram de um mesmo fundamento principiológico e consistam, todas elas, em manifestações da liberdade processual das partes. A segunda tese é que todas essas hipóteses de disponibilidade processual devem ser agrupadas sob a regência do princípio dispositivo devidamente redimensionado. São então estudadas concretamente algumas das manifestações de disponibilidade processual, sempre com o intuito de compatibilizá-las com a natureza pública da função jurisdicional, a eventual indisponibilidade de direitos sobre os quais versa o processo e o respeito a direitos e interesses juridicamente protegidos de terceiros.

Palavras-chave: Disponibilidade processual; princípio dispositivo; publicismo; liberdade; princípio da demanda; correlação entre demanda e tutela jurisdicional; aquiescência; renúncia; desistência; disponibilidade fática; iura novit curia; convenções processuais. 


\section{RÉSUMÉ}

RAMINA DE LUCCA, Rodrigo. Le principe dispositif: les intérêts privés des parties et la nature publique du droit judiciaire privé. Doctorat en Droit. Faculté de Droit. Universidade de São Paulo, 2018.

Ce travail propose deux thèses. La première thèse est qu'il y a, au droit judiciaire privé brésilien, beaucoup de situations de disponibilité de la procédure et de l'instance qui ne sont pas étudiées et abordées d'une manière systématique par la doctrine, bien qu'elles reposent sur un même principe et soient des manifestations de la liberté processuelle des parties. La deuxième thèse est que toutes ces situations de disponibilité doivent être groupées sous la régence du principe dispositif, correctement renouvelé. Se sont donc étudiées, concrètement, quelques de ces manifestations du principe dispositif dans le but de les rendre compatible avec la nature publique du droit judiciaire privé, avec l'indisponibilité des droits substantiels et avec l'obligatoire respect des droits et des intérêts protégés des tiers.

Mots-clés: principe dispositif ; droit public; liberté ; principe de la demande ; principe de l'indisponibilité de l'objet du litige ; acquiescence ; la maîtrise de la matière litigieuse ; la délimitation des faits ; iura novit curia ; les conventions relatives au procès. 


\begin{abstract}
RAMINA DE LUCCA, Rodrigo. Liberty in Litigation: private interests and the public nature of civil procedure. Doctorate in Law. Law School. Universidade de São Paulo, 2018.

The author presents two theses. The first thesis is that there are, in Brazilian civil procedure, several situations in which the parties may act according to their private autonomy that do not receive a systematical approach by the doctrine, although these situations derive from the same principle and represent, all of them, acts of procedural liberty. The second thesis is that all these situations of procedural liberty should be grouped together under the rule of a renewed principle of party-presentation. Once established these theses, then some of the manifestations of the parties' procedural liberty are studied in order to make them compatible with the public nature of civil procedure.
\end{abstract}

Keywords: Principle of party-presentation; liberty; adversarial system; inquisitorial system; due process of law. 
INTRODUÇÃO

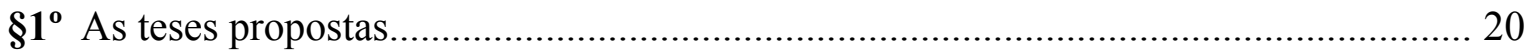

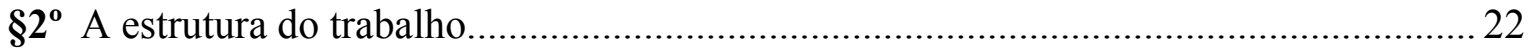

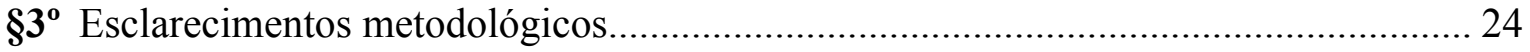

\section{CAPÍTULO PRIMEIRO - O PRINCÍPIO DISPOSITIVO}

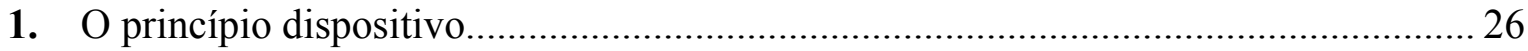

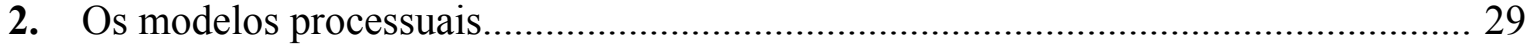

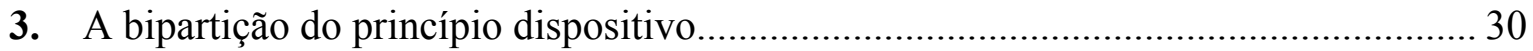

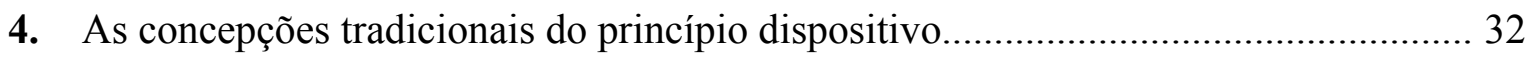

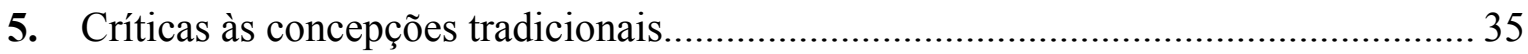

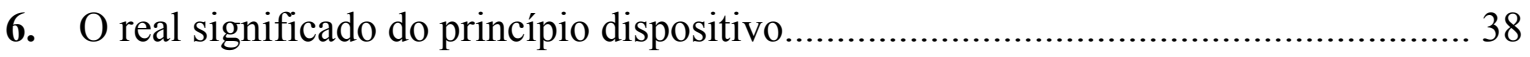

7. Fundamentos do princípio dispositivo: liberdade, imparcialidade e

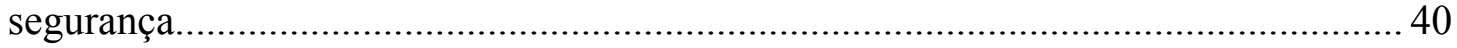

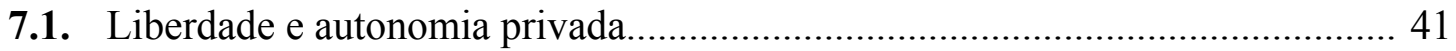

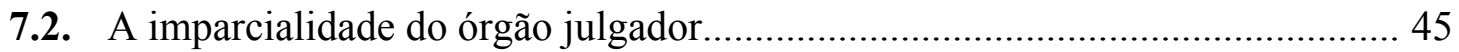

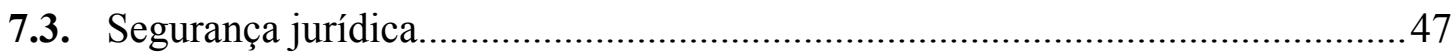

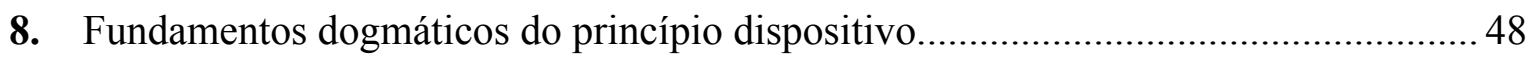

9. Princípio dispositivo e o sistema de ônus processuais.................................................. 49

10. Manifestações do princípio dispositivo: disponibilidade jurisdicional e disponibilidade

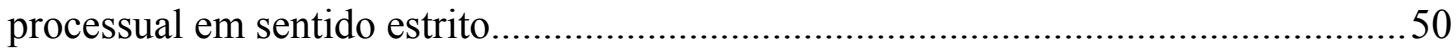

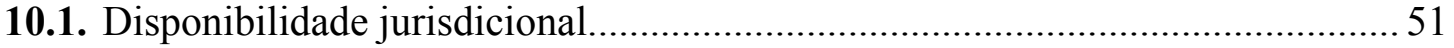

10.2. Disponibilidade processual em sentido estrito..................................................53

11. Autonomia privada e o dogma da irrelevância da vontade das partes no processo

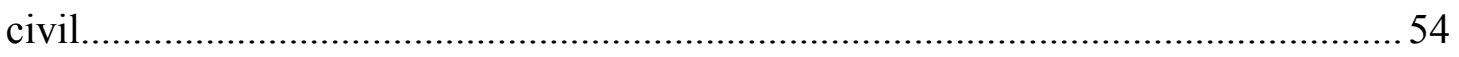

12. Disponibilidade processual e disponibilidade material.............................................56

13. Princípio dispositivo e os chamados "processos inquisitivos" (ou processos

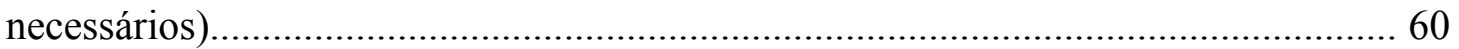

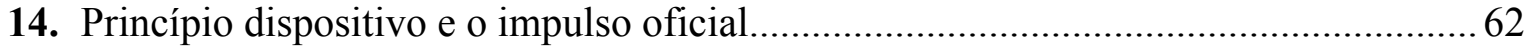

15. Princípio dispositivo e os poderes instrutórios do juiz...................................................66

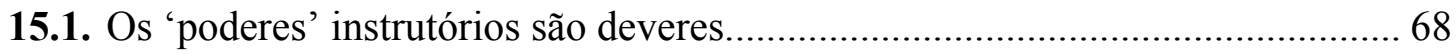


15.2. A solução para o problema dos deveres-poderes instrutórios: diálogo e informação.

\section{CAPÍTULO SEGUNDO - CAPÍTULO SEGUNDO - A PUBLICIZAÇÃO DO PROCESSO E A DERROCADA DO PRINCÍPIO DISPOSITIVO}

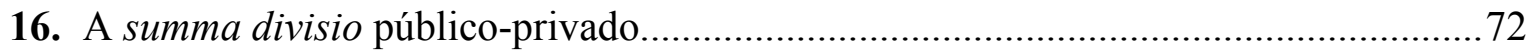

17. Os problemas da aplicação da summa divisio ao processo civil...................................74

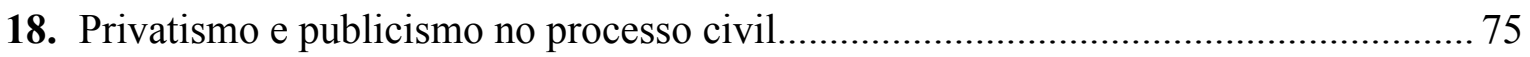

19. O processo civil contratual do ordo iudiciorum privatorum e a publicização do processo

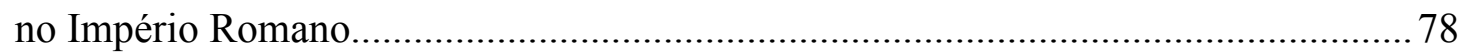

20. O novo ciclo entre privatismo e publicismo na Baixa Idade Média............................ 84

21. A formação do Direito Comum e a instituição das bases para o publicismo do processo moderno.

22. O processo civil moderno e a domesticação da função jurisdicional: o processo francês napoleônico......

23. O nascimento do Direito Processual como ciência autônoma: a abstração do poder de ação e os pressupostos processuais de Bülow 100

23.1. A abstração do poder de ação 101

23.2. Os pressupostos processuais e a relação jurídica processual pública. 104

24. O Código de Klein e a função social do processo. 106

25. As raízes socialistas do Código de Klein: a obra de Anton Menger. 111

26. A adoção da doutrina 'publicística' por Giuseppe Chiovenda. 114

27. A importância da obra de Chiovenda e a difusão do 'publicismo' na Itália 117

28. O Código de Processo Civil brasileiro de 1939. 118

29. O Código de Processo Civil italiano de 1940 121

30. O Código de Processo Civil português de 1939, "reformado" em 1961.................. 124

31. O Código de Processo Civil soviético de 1964 126

32. O Código de Processo Civil da República Democrática Alemã (Alemanha Oriental) de 1975.

33. As consequências da 'publicização' e a desvalorização da autonomia privada no processo civil: a rejeição do princípio dispositivo pela doutrina publicística 


\section{CAPÍTULO TERCEIRO - O RESGATE DO PRINCÍPIO DISPOSITIVO E O EQUILÍBRIO ENTRE LIBERDADE E AUTORIDADE}

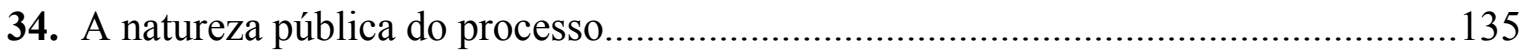

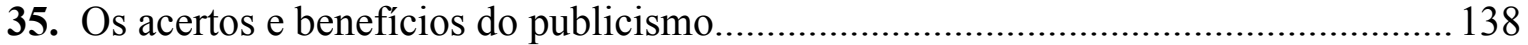

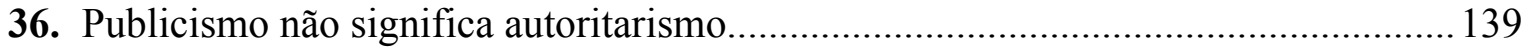

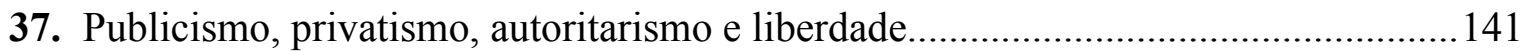

38. O publicismo deve servir aos jurisdicionados, e não ao Estado................................ 142

39. A superação dos mitos do publicismo-autoritário....................................................... 146

39.1. O mito de que sistemas autoritários reduzem os poderes do juiz: a abolição do

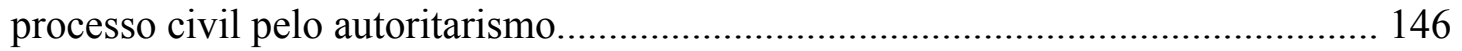

39.2. O mito da atribuição de poderes ao juiz para a busca da verdade material...... 150 39.3. O mito das decisões 'justas': a função do processo e do devido processo legal.

40. Os problemas do "princípio da cooperação" e a sua inaptidão para substituir o princípio dispositivo.

41. A saturação do autoritarismo e o resgate do princípio dispositivo............................. 160

42. O princípio dispositivo como princípio de liberdade................................................... 164

\section{CAPÍTULO QUARTO - A DISPONIBILIDADE DA AÇÃO E DA DEMANDA}

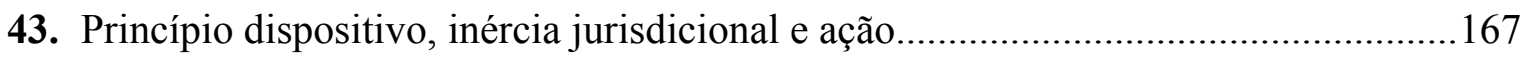

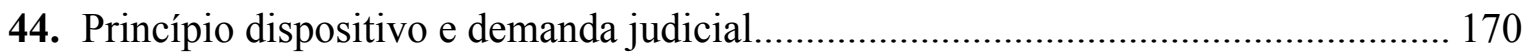

45. Princípio dispositivo e o mérito do processo.............................................................. 172

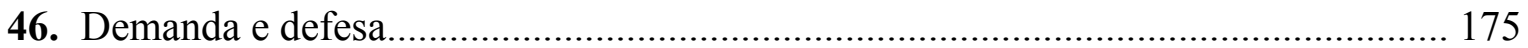

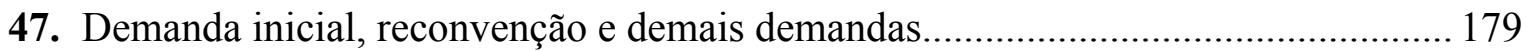

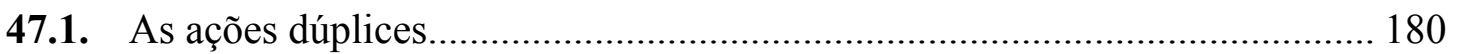

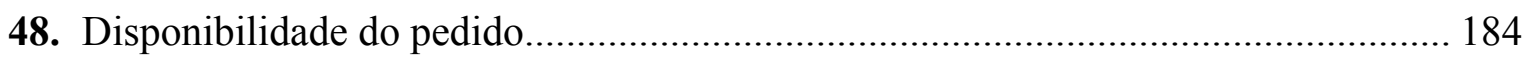

48.1. Disponibilidade do pedido, certeza e determinação....................................... 187

48.2. A cumulação "própria” de pedidos: simples e sucessiva................................. 188

48.3. A cumulação "imprópria" de pedidos: eventual e alternativa.......................... 190

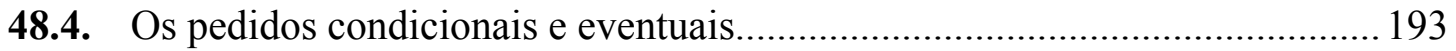

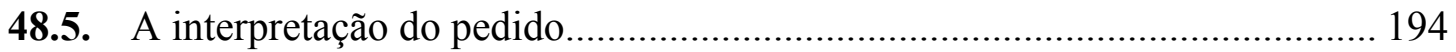

48.6. A inexistência de pedidos implícitos............................................................. 199

48.7. A inclusão de matérias no objeto do processo por determinação legal..........200 
48.8. A alteração do pedido por manifestação de vontade das partes 201

49. A disponibilidade sobre a composição dos polos processuais. 202

49.1. A composição dos polos processuais........................................................... 203

49.2. A exigência da legitimidade ad causam...................................................... 204

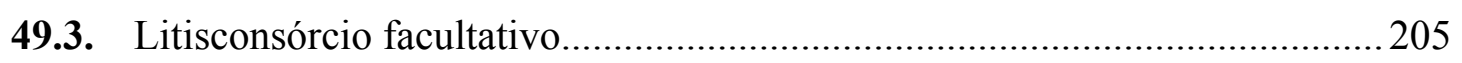

49.4. Litisconsórcio facultativo: alternativo, eventual e sucessivo........................ 208

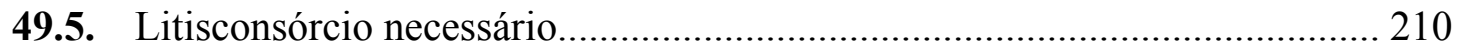

49.6. A excepcionalidade do litisconsórcio necessário.................................. 211

49.7. Inexistência de litisconsórcio ativo necessário............................................ 215

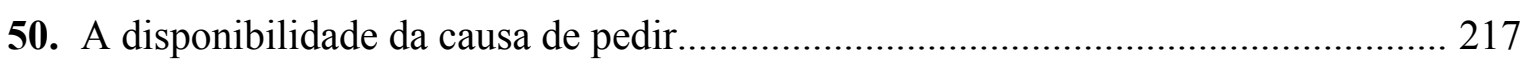

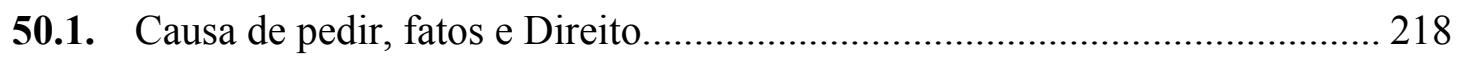

50.2. Cumulação de causas..................................................................... 224

50.3. A inexistência de causas de pedir implícitas................................................. 225

51. A indisponibilidade da ação e da demanda pelo Estado: a regra da

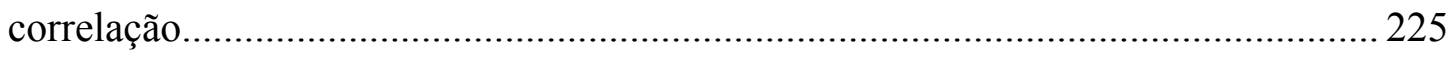

51.1. A correlação e os elementos da demanda......................................................228

51.2. Decisões extra petita, citra petita e ultra petita............................................ 229

52. A correlação entre pedido, decisão e coisa julgada.................................................. 233

\section{CAPÍTULO QUINTO - A DISPONIBILIDADE DO RESULTADO DO PROCESSO}

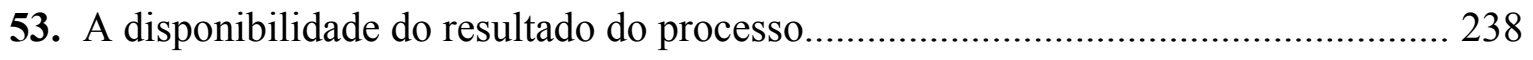

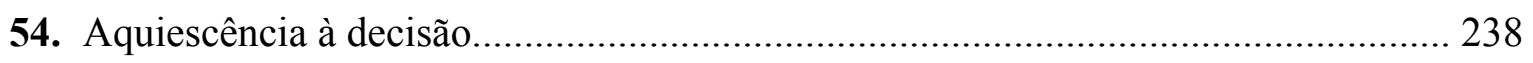

54.1. Hipóteses de aquiescência à decisão: expressa ou tácita, total ou parcial..... 242

54.2. Sobre os limites temporais à aquiescência à decisão.................................... 244

54.3. Aquiescência à decisão e a interposição de recursos..................................... 245

54.4. O efeito devolutivo dos recursos e a aquiescência parcial........................... 247

54.5. A proibição da reformatio in peius............................................................. 250

54.6. Efeito devolutivo e as questões de ordem pública ................................ 252

54.7. Os limites do chamado "efeito translativo" e o princípio dispositivo.............253

54.8. A renúncia à faculdade recursal e a desistência do recurso........................... 255

54.9. A legítima restrição da liberdade da parte para a tutela dos litisconsortes

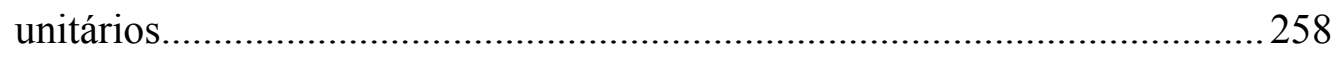

54.10. A legítima restrição da liberdade da parte para a tutela de terceiros...............259

54.11. Aquiescência, renúncia, desistência e os recursos adesivos...........................261 
54.12. Sobre os limites temporais à renúncia ao recurso e à desistência do recurso

54.13. Sobre a rejeição da desistência do recurso para que o tribunal possa criar precedentes. 266

54.14. Aquiescência, renúncia, desistência e direitos indisponíveis 269

54.15. Aquiescência, renúncia, desistência e ação rescisória. .270

55. Transação. 270

55.1. Os limites da atividade judicial na transação. 272

56. Renúncia à pretensão (art. 487, III, c do NCPC) 273

56.1. A confusão entre renúncia processual e renúncia material. 274

56.2. Renúncia à pretensão processual, e não ao direito. 276

56.3. A natureza da sentença fundada na renúncia. .280

56.4. As consequências da renúncia à pretensão no plano material .281

56.5. Limites à renúncia à pretensão: a disponibilidade material. 283

56.6. Segue: a inexistência de decisão de mérito transitada em julgado. .285

57. Reconhecimento da procedência do pedido. 286

57.1. Reconhecimento parcial ou total do pedido...... 286

57.2. A natureza processual do instituto. 287

57.3. Reconhecimento do pedido e confissão. 290

57.4. Reconhecimento do pedido e direitos indisponíveis 291

57.5. A eficácia vinculante do reconhecimento do pedido. .291

57.6. A rejeição do instituto pela doutrina italiana e pelo codice di procedura civile de 1940 .292

57.7. Os problemas da eficácia vinculante do reconhecimento do pedido...... .294

57.8. A fundamental diferença entre o julgamento fundado no reconhecimento do pedido e a homologação da transação. .296

57.9. Os limites ao reconhecimento do pedido: proposta de equilíbrio entre a liberdade do réu e a função jurisdicional. 297

58. Rescindibilidade das sentenças fundadas em atos de disposição. .300

\section{CAPÍTULO SEXTO - A DISPONIBILIDADE FÁTICA}

59. O princípio dispositivo e o monopólio da apresentação dos fatos pelas partes: o ônus da alegação. 306

60. Fatos primários (essenciais) e fatos secundários (simples). 308 
61. A disponibilidade dos fatos primários: a causa de pedir.

61.1. O art. 493 do NCPC e a suposta inserção de fatos novos no processo de ofício

62. A disponibilidade dos fatos primários: os fatos extintivos, modificativos e impeditivos

63. A disponibilidade dos fatos secundários. 325

64. A disponibilidade fática e a verdade processual: os consensos fáticos estabelecidos pelas partes. 326

65. Confissão 328

65.1. Confissão e admissão. 331

65.2. Confissão e os fatos que não são contrários ao próprio interesse 332

65.3. Os efeitos da confissão: críticas à concepção de que a confissão de fatos disponíveis não é vinculante ao Estado-juiz. 334

66. A admissão dos fatos: o efeito vinculante da incontrovérsia. 336

66.1. O efeito vinculante do fato admitido 337

66.2. A admissão dos fatos e a revelia. 339

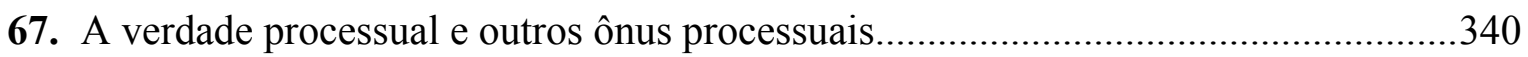

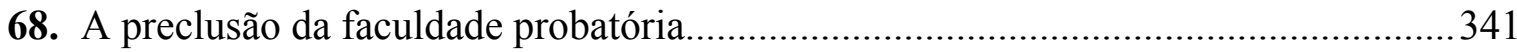

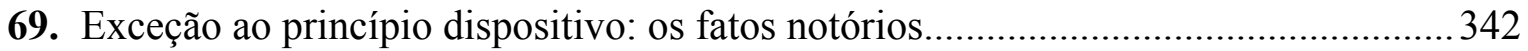

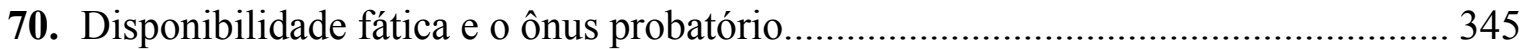

71. Disponibilidade fática e os deveres-poderes instrutórios do juiz...............................347

\section{CAPÍTULO SÉTIMO - A INDISPONIBILIDADE JURÍDICA (IURA NOVIT CURIA)}

72. A divisão de atribuições entre juiz e partes: o monopólio dos fatos pelas partes e o monopólio do Direito pelo juiz.

73. A indisponibilidade do Direito: o "princípio de jurisdição" 350

74. A indisponibilidade do Direito e a disponibilidade jurídica. 353

75. O aforismo iura novit curia. 354

76. As fontes do aforismo iura novit curia. 355

77. As cinco consequências fundamentais do iura novit curia no processo civil. 358

78. O significado do art. $357, \S 2^{\circ}$ do NCPC. 360

79. Limites ao iura novit curia: a decisão judicial não pode se afastar do mérito ou dos fatos alegados pelas partes .361

80. O iura novit curia é um dever imposto ao juiz, e não uma faculdade 363 


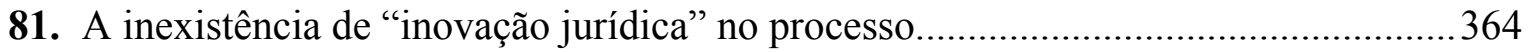

82. A oposição de embargos de declaração para suprir omissões jurídicas.......................366

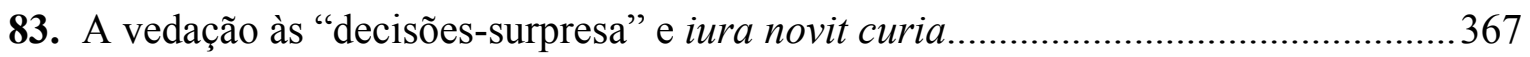

84. A “exceção" à indisponibilidade do Direito: prova de normas jurídicas não vigentes no

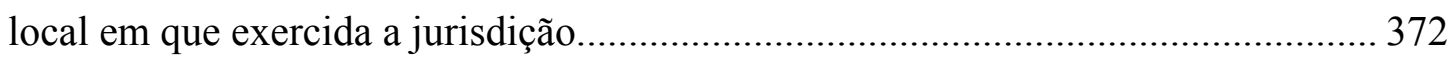

85. A indisponibilidade do Direito e os juízos de equidade.............................................373

\section{CAPÍTULO OITAVO - DISPONIBILIDADE PROCESSUAL EM SENTIDO ESTRITO}

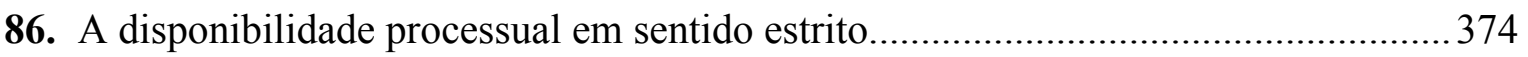

86.1. A indisponibilidade processual em sentido estrito: as questões de ordem

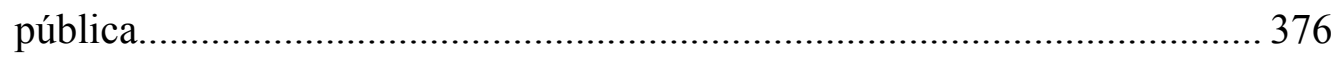

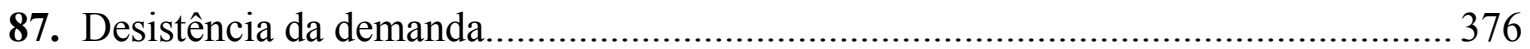

87.1. Sobre a concordância do réu com a desistência da demanda...........................378

87.2. A injustificada exceção do art. 1.040, $\S \S 1^{\circ}$ a $3^{\circ}$ do NCPC........................... 380

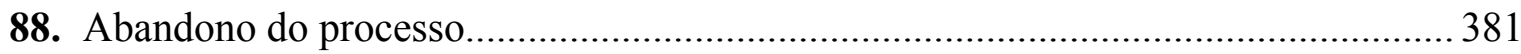

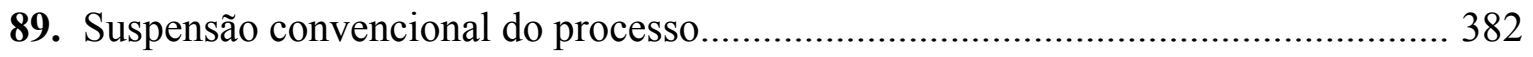

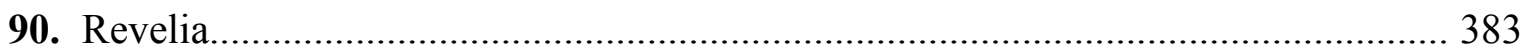

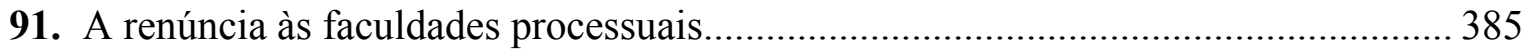

92. A desistência pela parte de faculdades processuais previamente exercidas................386

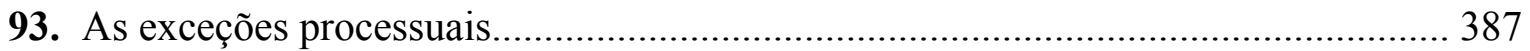

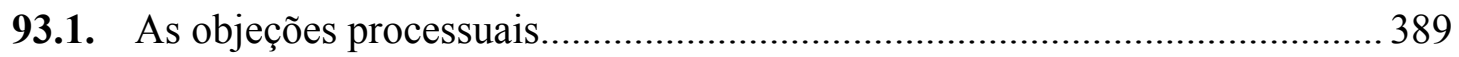

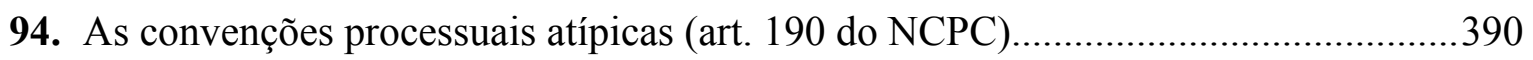

94.1. Pressupostos de existência e validade das convenções processuais................393

94.2. Limites às convenções processuais: validade e restrições legais.................... 395

94.3. Controle judicial das convenções processuais..............................................402

94.4. A liberdade das partes e a disponibilidade das faculdades e garantias

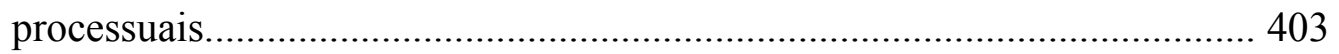

94.5. A regra geral sobre a licitude do objeto das convenções processuais............ 405

94.6. As questões indisponíveis e de ordem pública................................................. 405

94.7. Sobre as convenções envolvendo questões de ordem pública que interessam às

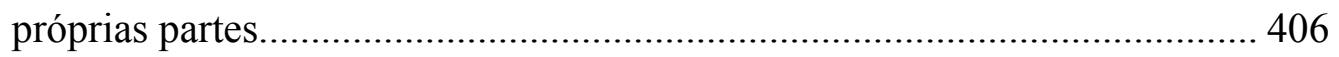

94.8. A impossibilidade de disposição sobre ônus, faculdades, poderes, deveres e

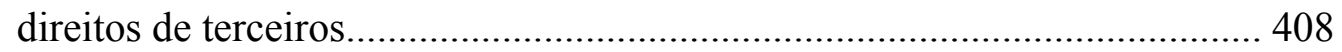

94.9. A vinculação do Estado-jurisdição às convenções processuais: limites........ 408 
94.10. A criação de obrigações processuais 410

94.11. As consequências do descumprimento da convenção processual.................. 410

94.12. O distrato e a novação da convenção processual.......................................... 411

94.13. Sobre a proposta de convenção processual................................................... 412

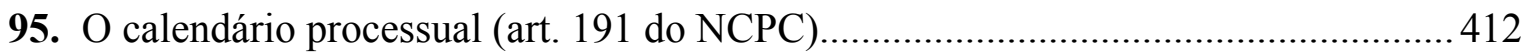

CONCLUSÃO

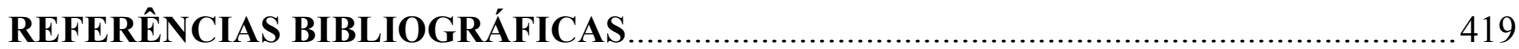




\section{INTRODUÇÃO}

Talvez nenhum outro tema seja tão estrutural e gere tantas consequências ao Direito Processual quanto as relações entre os interesses privados das partes que compõem os polos do processo e o interesse público do Estado na prestação jurisdicional.

Com efeito, desde a segunda metade do século XIX, o desenvolvimento processual foi pautado pelo pensamento de que o processo e a jurisdição não servem apenas às partes, mas desempenham relevante função pública - a chamada "função social do processo". A concepção publicística do processo foi determinante ao florescimento do Direito Processual como ciência autônoma do Direito Material, seja ao permitir o rompimento com a teoria imanentista da ação, seja ao impulsionar a sistematização dos pressupostos processuais por Bülow - considerado o marco do nascimento da ciência processual.

O publicismo processual marcou profundamente a doutrina italiana do século XX. Chiovenda, p.ex., defendia que a função precípua da jurisdição era realizar o direito objetivo mediante uma "relação jurídica de direito público de fato independente da relação substancial que é objeto da lide"; ${ }^{1}$ para Carnelutti, não era o processo que servia às partes, mas as partes que serviam ao processo ao proporcionar ao Estado a oportunidade de aplicar o direito ${ }^{2}$ Calamandrei criticou a "lide" de Carnelutti por acentuar o interesse privado das partes, denotando uma concepção privatista e, portanto, ultrapassada do processo. ${ }^{3} \mathrm{E}$ assim foi durante as décadas seguintes.

A França, marcada pela dualidade (ou trialidade) jurisdicional e uma profunda divisão entre Direito Público e Direito Privado, ${ }^{4}$ observa a sua doutrina moderna

\footnotetext{
${ }^{1}$ CHIOVENDA, Giuseppe. Del sistema negli studi del processo civile. p. 233.

${ }^{2}$ CARNELUTTI, Francesco. Sistema di Diritto Processuale Civile. p. 409.

${ }^{3}$ CALAMANDREI, Piero. Il concetto di “lite” nel pensiero di Francesco Carnelutti. p. 204 e ss.

${ }^{4}$ Todo o sistema de ensino jurídico francês, incluindo a carreira docente, é pautado na divisão entre Direito Público e Direito Privado. Sobre o tema, BONNET, Baptiste; DEUMIER, Pascale. Avant-propos. p. IX-X; BONNET, Baptiste. La summa divisio droit public-droit privé, chimère ou pierre angulaire? p. 3 e ss.;
} 
render-se ao publicismo processual, inclusive no que diz respeito ao processo desenvolvido na jurisdição judiciária "privada". 5

Ao final da década de 90 do século passado, a Inglaterra editou um "Código de Processo Civil" (Civil Procedure Rules) com um objetivo bastante claro: retirar o processo do controle das partes e transferi-lo aos tribunais. ${ }^{6}$ Faziam parte das diretrizes do novo processo civil inglês a descoberta da verdade, a proporcionalidade e a celeridade. ${ }^{7}$

A publicização do processo é, portanto, um fenômeno generalizado que, em maior ou menor medida, atingiu e tem atingido os países de tradição jurídica ocidental.

Esse movimento publicista tem razão de ser. A institucionalização do poder pelo Estado Moderno, que assumiu o monopólio da função jurisdicional, fez com que o privatismo em seu estado puro se tornasse incompatível com o processo estatal atualmente vigente. A jurisdição é exercício de poder público e o processo, instrumento de disciplina desse poder, tem natureza pública.

Além disso, reconhecer a natureza pública do Direito Processual é importantíssimo para estabelecer o regime jurídico aplicável à interpretação e aplicação das normas processuais. Em ensaio recente, Teresa Arruda Alvim foi muito feliz ao tratar dos “ambientes decisionais" e demonstrar que, por ter natureza pública, o Direito Processual é um "ambiente decisional rígido", intolerante a mudanças jurisprudenciais bruscas e repentinas. $^{8}$

A publicização do Direito Processual, porém, caminhou em direção a um hiperpublicismo danoso, autoritário, que acabou por sufocar os verdadeiros interessados -

CAPORAL, Stéphane. La summa divisio des facultés. p. 215 e ss.; BOUDOT, Michel. L'enseignement du droit, un instrument de la summa divisio? p. 245 e ss.

${ }^{5}$ Nesse sentido, CADIET, Loïc; JEULAND, Emmanuel. Droit Judiciaire Privé. p. 6-7; CADIET, Loïc; NORMAND, Jacques; MEKKI, Soraya Amrani. Théorie Générale du Procès. p. 108. Reconhecendo a natureza pública do "direito judiciário privado", mas minimizando sua importância, HÉRON, Jacques; BARS, Thierry Le. Droit Judiciaire Privé. p. 25.

${ }^{6}$ Exatamente nesse sentido, ao tratar do "overriding objective of the Civil Procedure Rules", Adrian Zuckerman escreveu: "Control over litigation has been taken away from the parties and entrusted to the court, thereby enabling the court to determine the best way of proceeding to a resolution to a dispute" (ZUCKERMAN, Adrian. On Civil Procedure: principles of practice. p. 1).

${ }^{7}$ ZUCKERMAN, Adrian. On Civil Procedure: principles of practice. p. 3-15.

${ }^{8}$ ALVIM, Teresa Arruda. Precedentes e evolução do direito. p. 52-57. 
ao menos diretamente - na prestação jurisdicional: as partes. Os poderes do juiz foram excessivamente majorados e todos os atos processuais relevantes passaram a ser voltados unicamente à figura judicial. É o caso, p.ex., entre muitas outras hipóteses, da indisponibilidade do procedimento pelas partes, da concepção de que o ônus da prova é mera regra de julgamento a ser definida na sentença (impedindo as partes de saber quais provas são de sua responsabilidade e quais não são), da crença de que o juiz é o único destinatário da prova, da atribuição de 'poderes' instrutórios 'facultativos' ao juiz, a serem exercidos quando ele bem quiser, da rejeição de qualquer diálogo prévio entre juiz e partes antes de proferida a decisão etc.

Dois exemplos desse publicismo extremado podem ser encontrados na jurisprudência recente do nosso Superior Tribunal de Justiça. As decisões foram proferidas sob a vigência do CPC/73, mas ainda assim servem a título ilustrativo.

Em mais de uma oportunidade o STJ decidiu que a produção de provas (matéria que deveria ser disponível pelas partes) é uma questão de ordem pública insuscetível de preclusão. Desse modo, mesmo que a parte não tivesse interposto recurso da decisão que indeferiu a produção de determinada prova, poderia rediscutir a questão posteriormente em recurso de apelação. O fundamento de tais decisões seria justamente a natureza pública do processo e a necessidade de se obter a verdade material para a prolação de decisões justas. ${ }^{9}$

9 PROCESSUAL CIVIL. EMBARGOS DE DECLARAÇÃO NO AGRAVO DE INSTRUMENTO. PRINCÍPIOS DA ECONOMIA PROCESSUAL E FUNGIBILIDADE. AGRAVO REGIMENTAL. PRODUÇÃO DE PROVA. CERCEAMENTO DE DEFESA. QUESTÃO DECIDIDA NO MOMENTO DO SANEAMENTO. PRECLUSÃO. INEXISTÊNCIA, MATÉRIA DE ORDEM PÚBLICA. PRECEDENTES. SÚMULA N. 83/STJ. (...) 2. As matérias de ordem pública decididas por ocasião do despacho saneador não precluem, podendo ser suscitadas na apelação, ainda que a parte não tenha interposto o recurso de agravo. (...) (STJ, EDcl no Ag 1378731/PR, julgado em 14/05/2013)

PROCESSO CIVIL. PROVA. PEDIDO. APRECIAÇÃO. MOMENTO. OITIVA DE TESTEMUNHA POR CARTA ROGATÓRIA REQUERIDA ANTES DO SANEAMENTO. SUSPENSÃO DO PROCESSO. CONDIÇÕES. (...) 2. Nos termos do art. 130 do CPC, não há preclusão absoluta em matéria de prova, até por se tratar de questão de ordem pública. Mesmo proferido o despacho saneador, o juiz pode, mais tarde, determinar a realização de outras provas, caso entenda que essa providência é necessária à instrução do processo. (...) (STJ, REsp 1.132.818/SP, DJe de 10/5/2012) 
O segundo exemplo é a conhecida decisão do STJ que rejeitou uma desistência de recurso amparada em transação porque o julgamento do caso seria relevante à sociedade e à homogeneização de um tema controverso. De acordo com a decisão, "o julgamento dos recursos submetidos ao STJ ultrapassa o interesse individual das partes nele envolvidas, alcançando toda a coletividade para a qual suas decisões irradiam efeitos". ${ }^{10}$

Ambas as hipóteses revelam uma concepção distorcida do publicismo que tolhe a liberdade das partes e as relega a um segundo plano. De protagonistas do processo as partes passam a ser coadjuvantes do Estado-juiz. ${ }^{11}$

Por isso, as incisivas críticas ao publicismo processual autoritário europeu, iniciadas principalmente por Franco Cipriani, às quais foram aderidas por autores como Juan Montero Aroca e Girolamo Monteleone, ${ }^{12}$ têm repercutido na doutrina e, ainda que algumas vezes extremadas, foram importantíssimas para promover a reflexão sobre o verdadeiro papel das partes no processo.

Afinal, se é verdade que o processo tem natureza pública, e se é verdade que a realização, homogeneização e integração do direito objetivo é tarefa da mais elevada importância, também é verdade que a função precípua do processo é tutelar e efetivar os direitos juridicamente assegurados das partes ou de quem elas extraordinariamente representam. Existe uma simbiose entre as atividades, tal qual escreveu Tito Carnarcini na década de 50: "se o processo serve às partes, por sua vez as partes servem ao processo". ${ }^{13}$

Além disso, nem sempre privatismo e publicismo estabelecem relações de tensão. A maioria das questões de ordem pública e dos institutos publicísticos são voltados à tutela do próprio jurisdicionado, e não do Estado em si mesmo considerado. E não poderia ser diferente. O Estado não é um fim em si mesmo, mas instrumento de promoção da

\footnotetext{
${ }^{10}$ STJ, QO em REsp n⿳ 1308830/RS, j. 08.05.2012.

${ }^{11}$ Nas palavras de Leonardo Greco, “(...) [as partes], como destinatárias da prestação jurisdicional, também têm interesse em influir na atividade-meio e, em certas circunstâncias, estão mais habilitadas do que o próprio julgador a adotar decisões sobre os seus rumos e a ditar providências em harmonia com os princípios publicísticos do processo (...)" GRECO, Leonardo. Os atos de disposição processual-primeiras reflexões. p. 290-291.

${ }^{12}$ Compiladas na coletânea Processo Civil e Ideología, contando também com trabalhos de Giovanni Verde, Juan Picó i Junoy e Barbosa Moreira em defesa do 'publicismo’.

${ }^{13}$ CARNACINI, Tito. Tutela giurisdizionale e tecnica del processo. p. 700.: "se il processo serve alle parti, alla loro volta le parti servono al processo".
} 
dignidade da pessoa humana. A natureza pública do processo deve ser compreendida sempre à luz do jurisdicionado, e não dos interesses do próprio Estado (não raro conflitantes com o interesse público).

Isso quer dizer que publicismo e privatismo não só convivem no processo estatal, como devem conviver harmoniosamente, complementando-se de modo a viabilizar um processo regido pelo devido processo legal que proporcione os meios necessários a se alcançar um resultado justo (i.e., juridicamente correto).

Essa dicotomia público-privado está presente no Novo Código de Processo Civil brasileiro de forma muito evidente. Ao mesmo tempo em que o legislador buscou ampliar a eficácia da função pública desempenhada pela jurisdição, atribuiu novos poderes e faculdades às partes.

Há vários institutos essencialmente publicísticos, sobretudo no que diz respeito à (correta) valorização dos precedentes. Atribuiu-se eficácia vinculante a determinadas decisões (art. 927), autorizou-se o julgamento de questões jurídicas pelos tribunais mesmo depois da desistência do recurso pela parte (art. 998, parágrafo único), tratou-se com mais severidade a má-fé (art. 81), estabeleceu-se um incidente processual para o julgamento de causas com grande repercussão social (incidente de assunção de competência - art. 947) etc.

Do ponto de vista da disponibilidade privada, o NCPC aderiu ao movimento, que tem se difundido também em outros países, ${ }^{14}$ de outorga de poderes às partes para que adaptem o processo ao caso concreto. Nesse sentido, o art. 190 permite a ampla realização de convenções processuais atípicas para "estipular mudanças no procedimento para ajustálo às especificidades da causa e convencionar sobre os seus ônus, poderes, faculdades e deveres processuais, antes ou durante o processo".

Essa liberdade conferida às partes de convencionarem, certamente uma das mais destacadas novidades do Novo Código, vem sendo recebida com grande entusiasmo pela comunidade jurídica e tem estimulado uma produção doutrinária fértil e ampla. A

\footnotetext{
${ }^{14}$ V., p.ex., a edição especial da Rivista Trimestrale di Diritto e Procedura Civile, publicada em 2008, intitulada Accordi di Parte e Processo.
} 
autonomia privada no processo, ${ }^{15}$ bem como os limites impostos à disponibilidade processual convencional, tornaram-se objeto de louvável estudo teórico.

Não se pode esquecer, porém, que a hipótese das convenções processuais é apenas uma das variadas manifestações de disponibilidade processual. E a doutrina não tem se preocupado em estudá-las de forma sistemática e coordenada.

O objetivo deste trabalho é, portanto, suprir essa lacuna. O princípio dispositivo há muito tempo deixou de receber tratamento homogêneo pela doutrina do Direito Processual, se é que alguma vez esse tratamento homogêneo existiu. Ora o princípio é considerado sinônimo do "princípio da demanda" e da regra de adstrição do juiz ao pedido, tendo como significado a possibilidade outorgada à parte de escolher o que será levado a juízo para julgamento; ora é tratado como princípio norteador do sistema processual acusatório; ora é confundido com a disponibilidade do próprio direito material; e, não raro, é compreendido meramente como vedação a iniciativas probatórias do juiz.

É preciso, então, agrupar as manifestações de liberdade processual das partes, atribuir ao princípio dispositivo uma função realmente útil no sistema, confrontá-lo com os interesses públicos e estabelecer diretrizes para que ambos possam conviver de forma harmoniosa e complementar.

\section{$\S 1^{\circ}$. As teses propostas}

Este trabalho possui duas teses centrais que conferem ineditismo ao estudo.

A primeira tese central é que existem no Direito Processual Civil brasileiro diversas hipóteses de disponibilidade processual e procedimental que não são estudadas e enfrentadas de forma sistemática, embora decorram de um mesmo fundamento principiológico e consistam, todas elas, em manifestações da liberdade processual das partes. Sem prejuízo da farta produção bibliográfica recente acerca das convenções processuais atípicas inseridas em nosso sistema processual pelo art. 190 do NCPC, tais convenções não são estudadas como parte de um fenômeno mais amplo que inclui, p.ex., a delimitação da demanda, a revelia, a confissão, a admissão, a renúncia a faculdades processuais, a

\footnotetext{
${ }^{15}$ P.ex., RAATZ, Igor. Autonomia Privada e Processo Civil. p. 158 e ss.
} 
desistência de faculdades processuais exercidas, a aquiescência à decisão, a renúncia à pretensão etc. ${ }^{16}$

A segunda tese central deste trabalho, vinculada à primeira, é que todas essas hipóteses de disponibilidade processual devem ser agrupadas sob a regência do princípio dispositivo. É preciso abandonar o sentido restritivo que se atribui ao princípio, ainda vinculado a uma formulação teórica da primeira década do século XIX. De nada adianta à ciência processual um princípio que se confunde com uma única regra dele derivada (a regra da inércia jurisdicional); ou, pior, com uma regra que nem sequer foi acolhida pelo Direito brasileiro (a regra da iniciativa probatória exclusiva das partes).

O que se propõe então é que o conceito de princípio dispositivo seja devidamente resgatado e redimensionado, conferindo-lhe a função de representar a autonomia privada das partes no processo ou, talvez mais precisamente, de traduzir objetivamente um "princípio de liberdade processual".

Refuta-se, portanto, a teoria que vem se tornando dominante na doutrina brasileira de que o princípio dispositivo teria sido substituído pelo chamado "princípio da cooperação". Independentemente de sua validade ou acerto, o "princípio da cooperação" é incapaz de sistematizar as hipóteses em que as partes dispõem do processo e no processo como exercício de liberdade. Por maior que seja a amplitude dada à cooperação, a desistência de um recurso, p.ex., nada tem de atividade cooperativa.

Para se chegar a essas teses parte-se da premissa de que o Direito Processual, embora público, não existe para o Estado, mas para a pessoa. Rejeita-se a confusão entre processo e jurisdição, ideias estritamente relacionadas, mas autônomas e independentes. Se a jurisdição é a função, a atividade e o poder do Estado, a qual precisa ser exercida com a máxima efetividade, o processo e o Direito Processual são a disciplina desse exercício jurisdicional. Isso quer dizer que o processo e o Direito Processual têm a específica função de proporcionar segurança jurídica e tutelar o indivíduo contra o exercício arbitrário do poder. O processo não serve para fazer justiça, mas para permitir que o Estado-jurisdicional faça a sua 'justiça' institucional com legitimidade. Essa diferença é imprescindível para

\footnotetext{
${ }^{16}$ Deu início a esse estudo GRECO, Leonardo. Os atos de disposição processual - primeiras reflexões. p. 290304, mas também com ênfase nas convenções processuais.
} 
estabelecer e disciplinar os pontos de conflito entre os interesses privados juridicamente tutelados das partes e os interesses público-estatais no exercício jurisdicional.

Proposto o resgate do princípio dispositivo, são então estudadas concretamente algumas de suas manifestações, sempre com o intuito de compatibilizá-las com a natureza pública da função jurisdicional, a eventual indisponibilidade de direitos sobre os quais versa o processo e o respeito a direitos e interesses juridicamente protegidos de terceiros. Dessa análise são extraídas subteses, das quais vale destacar a defesa: (a) da revalorização da inércia jurisdicional; (b) da revalorização da demanda e da adequada disciplina do objeto do processo; (c) da vedação de qualquer iniciativa judicial na inclusão de fatos primários no processo; (d) do rompimento com a teoria de que a renúncia à pretensão e o reconhecimento do pedido têm natureza material, e não processual; (e) da relativização da eficácia vinculante do reconhecimento do pedido em razão da natureza pública da função jurisdicional; (f) da revalorização da incontrovérsia fática em causas que versem sobre direitos disponíveis; (g) de que os fatos são, em maior ou menor medida, disponíveis; e (h) de que o processo judicial é regido pela indisponibilidade do Direito (iura novit curia).

\section{$\$ 2^{\circ}$ A estrutura do trabalho}

Para atingir a finalidade proposta, este trabalho é composto de oito capítulos. Os três primeiros têm como objetivo demonstrar as teses centrais, com o resgate do princípio dispositivo ao plano central do estudo do Direito Processual. Os cinco últimos são a demonstração concreta e prática de esferas de disponibilidade processual no processo de conhecimento, propondo-se então soluções para equilibrar a natureza pública do processo e os interesses privados das partes, sobretudo a liberdade.

O Capítulo Primeiro foca especificamente no princípio dispositivo. É descrita a origem do princípio com a obra de Gönner no início do século XIX e a divisão, a partir dela, entre modelos processuais antagônicos: o dispositivo e o inquisitivo. Apresentam-se as diversas concepções doutrinárias tradicionais do princípio, contemporaneamente fundadas na divisão entre "princípio da demanda" e iniciativa na produção da prova. Critica-se a excessiva restritividade das concepções tradicionais de princípio dispositivo e defende-se a sua ampliação para que ele possa representar a efetiva liberdade que as partes têm antes, durante e depois do processo.

O Capítulo Segundo, essencial ao trabalho e às ideias nele defendidas, apresenta uma breve narrativa da evolução do Direito Processual sob a perspectiva da summa 
divisio público-privado. Pretende-se demonstrar que a evolução do processo foi marcada por um movimento pendular, prevalecendo o publicismo à medida que se fortalecia uma fonte de poder soberana, ao passo que o privatismo imperava quando fragmentado esse poder central. Nesse exato sentido, o publicismo consolidou-se com o Estado Moderno e a institucionalização do poder, mas foi exacerbado nos diversos regimes ditatoriais do século XX. Muitos ideais atualmente considerados 'publicistas' serviram como fundamento teórico para a criação de sistemas processuais autoritários e autocentrados nos interesses estatais, atribuindo-se cada vez mais poderes aos juízes para o atingimento desses objetivos.

O Capítulo Terceiro conclui a fundamentação teórica do resgate do princípio dispositivo ao rejeitar o publicismo-autoritário, reafirmar a natureza pública do processo e os benefícios dela decorrentes, mas defender a revalorização da liberdade processual das partes. Para tanto, são questionados alguns dogmas 'publicistas', com a recolocação do Direito Processual em sua posição de instrumento de liberdade e segurança. Também se refuta a substituição do princípio dispositivo pelo chamado "princípio da cooperação".

O Capítulo Quarto aborda a disponibilidade da ação e da demanda, bem como, ao final, a indisponibilidade da tutela jurisdicional pelo Estado, a qual deve correlacionar-se estritamente aos limites do rompimento da sua inércia. Entre os temas estudados incluem-se o conceito de mérito e de objeto do processo e a liberdade do jurisdicionado para moldar a demanda às suas necessidades, incluindo eventuais cumulações.

O Capítulo Quinto apresenta o princípio dispositivo sob uma ótica pouco estudada, que é a disponibilidade do resultado do processo. Vale destacar a aquiescência à decisão como ato de disposição, a qual é normalmente examinada apenas sob o ponto de vista de pressuposto de admissibilidade dos recursos. Também são objeto de análise a desistência do recurso, a renúncia ao recurso, a transação, o reconhecimento da procedência do pedido e a renúncia à pretensão inicial. Em relação a esses dois últimos institutos, este trabalho afasta-se da doutrina brasileira praticamente unânime que os considera institutos de autocomposição e de disponibilidade essencialmente material. A partir de exemplos procurase demonstrar que ambos possuem natureza processual e que ambos produzem, imediatamente, efeitos primários processuais, e não materiais. Além disso, propõe-se uma maior amplitude à renúncia à pretensão quando envolver direitos indisponíveis e, por outro lado, limites mais estritos ao reconhecimento da procedência do pedido. 
O Capítulo Sexto estuda a disponibilidade fática no processo, a qual consiste, de um lado, no monopólio dos fatos primários pelas partes - incluindo os fatos de defesa do demandado - e, de outro, na vinculação do juiz às incontrovérsias fáticas estabelecidas processualmente, salvo quando a incontrovérsia tiver propósito fraudulento, o fato incontroverso for manifestamente absurdo ou impossível, ou a causa versar sobre direitos indisponíveis.

O Capítulo Sétimo explora e defende o iura novit curia, justificando os motivos pelos quais os fatos são disponíveis e o Direito é indisponível. Nega-se a possibilidade de convenção das partes para definir normas jurídicas aplicáveis ao caso ou para vincular o Estado-juiz a eventuais qualificações jurídicas - faculdade que existe apenas nas arbitragens.

Para concluir, o Capítulo Oitavo trata das hipóteses chamadas de “disponibilidade processual em sentido estrito", as quais consistem essencialmente em atos de disposição formal do processo, incluindo garantias, ônus, faculdades e poderes processuais. Foram escolhidas algumas hipóteses de disponibilidade que, além de importantes, confirmam as teses iniciais propostas.

\section{$\S^{\circ}$ Esclarecimentos metodológicos}

É muito difícil construir uma teoria de Direito Processual Civil coesa no Direito brasileiro. O mesmo processo civil é instrumento para a solução de conflitos entre particulares, para a solução de conflitos entre particulares e Administração Pública, para a atuação do Direito sem que haja conflito, para ações de improbidade, para ações populares, para ações coletivas etc. Ora se discutem no processo interesses exclusivamente particulares e disponíveis, ora interesses também particulares, mas indisponíveis, ora interesses públicos indisponíveis, ora interesses do Estado que não são necessariamente indisponíveis.

Essa amplitude faz com que o estudo do Direito Processual acabe enviesado pela abordagem que lhe é dada; princípios, valores, regras e postulados são apresentados como novas verdades de forma ampla e absoluta, muito embora prestem-se a resolver casos específicos e às vezes restritos, os quais estão longe de compor a realidade dos tribunais brasileiros. Rejeita-se genericamente a liberdade das partes sob a ótica de processos coletivos, p.ex., sem se dar conta que eventuais princípios que regem tais processos, embora de inestimável importância, não podem pautar toda a ciência processual. 
Este trabalho propõe-se a refletir sobre processos em que se discutem interesses privados, disponíveis ou indisponíveis. Não existe nenhuma pretensão de se dar, aqui, respostas sobre as relações entre publicismo e privatismo quando o Ministério Público agir em defesa do interesse público nem quando o Estado for parte processual. Também não se estuda o princípio dispositivo na perspectiva de processos coletivos. Qualquer tentativa teórica de englobar todas essas situações não está apenas fadada ao insucesso, mas, pior, impede que se compreendam as fundamentais diferenças entre elas, gerando distorções graves e involuções científicas.

Na verdade, não é exagero afirmar que parte significativa do atrofiamento do princípio dispositivo decorre de proposições teóricas formuladas a partir da experiência com processos em que não são discutidos interesses individuais.

Cumpre ainda esclarecer que o desenvolvimento deste tema específico é muito suscetível a influências ideológicas, tanto do autor quanto do leitor. Justamente por isso foram enfatizadas as análises histórica e de direito estrangeiro, a todo instante referenciadas e retomadas. Estudo histórico, aliás, que foi determinante a muitas das conclusões alcançadas neste trabalho. Desse modo, procurou-se insistentemente relacionar algumas ideias combatidas com sistemas processuais totalitários, demonstrando que o autoritarismo que eventualmente as caracterize não é uma mera opinião pré-concebida. Assim espera-se conferir maior cientificidade aos posicionamentos adotados e às teses propostas.

Por fim, com o intuito de aumentar a clareza e a acessibilidade, foram traduzidas ao português todas as citações feitas no corpo do texto. Sempre que este autor considerou necessário, seja pela importância, seja pela peculiaridade de certas expressões, seja ainda pela absoluta incapacidade de transmitir a mensagem senão por aquelas exatas palavras, as citações estrangeiras foram reproduzidas no original em nota de rodapé. As citações feitas diretamente em nota de rodapé, por não serem indispensáveis à compreensão do texto, foram traduzidas ao português apenas quando apresentavam importância destacada. 


\section{CONCLUSÃO}

$\mathrm{Na}$ trilogia dos objetivos jurídicos, o Direito Processual serve ao valor segurança. E ao servir ao valor segurança, serve ao valor liberdade.

Não se trata de conclusão enviesada por determinada ideologia, mas de uma irrefutável constatação de ordem lógica. Como foi exposto no Capítulo Terceiro, o Estado não precisa do processo para exercer a jurisdição. Basta investir agentes do poder jurisdicional, outorgando-lhes a prerrogativa de 'distribuir justiça' da maneira que considerarem mais adequada, célere e efetiva, sem nenhuma limitação formal préestabelecida. Foi exatamente essa, aliás, a proposta de processo ideal formulada por autores como Menger e Baumbach; e, em muitos aspectos, dela não se afastavam os sistemas processuais socialistas.

Se uma prestação jurisdicional dessa natureza é terminantemente vedada pelo nosso ordenamento jurídico, é porque sabe-se atualmente que todo poder estatal precisa ser disciplinado: é essa a grande conquista do Estado Moderno, regido pelo ideal do Estado de Direito. Disciplina-se o exercício do poder jurisdicional mediante a criação de um método de atuação, o processo, que deve ser rigorosamente seguido pelos agentes estatais para que, além de 'justa', a decisão ao final proferida seja legítima. Daí falar-se em devido processo legal, que é, lembrando as atemporais lições de Couture, a "garantia da liberdade".

Partindo-se do pressuposto de que o Direito Processual é instrumento de liberdade (e negá-lo impõe rejeitar a própria ciência processual, como tão bem concluiu Calamandrei), nada justifica a supressão da autonomia privada no processo promovida pelo movimento publicista-autoritário dos séculos XIX e XX. Houve um grave desvirtuamento das finalidades do processo e, paradoxalmente, um afastamento dos princípios e valores que regem o Direito Público. O processo passou a ser confundido com a jurisdição, e de instrumento que deveria servir ao jurisdicionado, transformou-se em instrumento do Estado para o próprio Estado.

É claro que, por ser a jurisdição uma atividade, uma função e um poder públicos, a liberdade processual encontra limites insuperáveis. Nenhuma liberdade é ilimitada. A autonomia privada das partes precisa compatibilizar-se com a noção de que o Estado presta algo muito próximo a um serviço público aos jurisdicionados, o qual não pode ficar refém de eventuais caprichos privados. 
Além disso, de forma nenhuma se pretende retornar a uma época em que o juiz permanecia inerte e pouco contribuía à efetividade do processo. Se é certo que o processo é instrumento de liberdade e de segurança, também é certo que ele não pode prejudicar a eficiência que se espera da prestação jurisdicional. Esse é um dos grandes méritos da publicização do processo, a qual, além de fomentar o desenvolvimento da ciência processual, foi determinante para que se conscientizasse que o Estado deve cumprir a sua missão jurisdicional com celeridade, qualidade e efetividade, pois é isso que esperam os seus destinatários.

Por isso, apenas uma má compreensão do princípio dispositivo permite contrapor a liberdade das partes com os deveres do juiz de impulsionar o processo e garantir que o processo caminhe celeremente (sem prejuízo da segurança) rumo à sua conclusão. Impulso oficial e princípio dispositivo não apenas convivem, mas complementam-se.

Também se depreende algum exagero, de ambos os lados, no intenso debate sobre os 'poderes' instrutórios do juiz. Menos importante do que os 'poderes' em si é o modo pelo qual esses 'poderes' são exercidos. É inadmissível, portanto, concebê-los como faculdades a serem exercidas ao livre arbítrio do julgador. Ou o juiz possui deveres-poderes instrutórios ou não possui nenhum poder. O que não se pode é supor que existem poderes judiciais exercidos facultativa e arbitrariamente. Ademais, a solução para que se profiram decisões com mais qualidade é o diálogo com as partes, e não o exercício autoritário, inesperado e não raro improdutivo de um poder estatal.

Mas feitas essas ressalvas, o que se procurou demonstrar é que todo o sistema processual é estruturado, em maior ou menor medida, sobre a noção de disponibilidade. Da sua instauração até a sua conclusão o processo é essencialmente regido por um sistema de ônus que torna todos os atos das partes facultativos. Mesmo quando a causa versa sobre direitos indisponíveis, embora se restrinjam os efeitos da incontrovérsia fática, o processo continua eminentemente dispositivo. A propositura da demanda é facultativa, a contestação é facultativa, a alegação de fatos é facultativa, a produção de provas é facultativa, o comparecimento para depor é facultativo, a interposição de recursos é facultativa. Enfim, ao contrário do dever de participação que regia os processos socialistas, o nosso processo é regido pela mais ampla liberdade individual.

A proposta deste trabalho foi, então, sistematizar essas hipóteses de disponibilidade processual sob a regência de um princípio dispositivo renovado e revigorado. 
Com efeito, é preciso parar de pensar o princípio dispositivo com a visão limitada de uma teoria criada no início do século XIX, em uma fase histórica na qual o processo não havia nem sequer adquirido a sua autonomia científica frente ao direito material. O princípio dispositivo não pode mais ser confundido com a prerrogativa outorgada ao jurisdicionado de romper a inércia jurisdicional e formular uma demanda. Embora essa seja a sua manifestação mais importante, não é a única. E com muito menos razão o princípio dispositivo pode ser reduzido à mera iniciativa das partes na produção de provas.

A conservação de uma doutrina já ultrapassada, que reduz o princípio dispositivo a uma ou duas manifestações processuais específicas, impede a constatação de que a inércia jurisdicional, a revelia, a confissão, a aquiescência à decisão, a desistência do recurso e as convenções processuais, dentre muitos outros exemplos, possuem uma mesma base principiológica, um mesmo fundamento sobre o qual se amparar. Todas essas hipóteses decorrem da liberdade que as partes têm no processo - são atos de disposição - e precisam ser estudadas como um todo orgânico. Apenas assim será possível desenvolver uma ciência processual coesa e coerente que saiba compatibilizar liberdade, 'justiça' e efetividade.

O publicismo-autoritário criado no século XX parece, ao menos no Brasil, ter atingido o seu ponto de saturação. É preciso agora recuperar o real significado da natureza pública do processo e compatibilizá-lo com a valorização da liberdade dos jurisdicionados, que é a razão de ser do Direito Processual. 


\section{REFERÊNCIAS BIBLIOGRÁFICAS}

ABREU, Alzira Alves de; et al. (coords.). Dicionário Histórico-Biográfico Brasileiro-Pós1930. Rio de Janeiro: CPDOC, 2010. Disponível em: <http://cpdoc.fgv.br.>

ADAMEK, Marcelo Vieira von; FRANÇA, Erasmo Valladão Azevedo e Novaes. Da Ação de Dissolução Parcial de Sociedade: comentários breves ao CPC/2015. São Paulo: Malheiros, 2016.

ALEXY, Robert. Teoria dos Direitos Fundamentais. Trad. Virgílio Afonso da Silva. São Paulo: Malheiros, 2008.

ALMEIDA JÚNIOR, João Mendes de. Direito Judiciário Brasileiro. Livraria Freitas Bastos. São Paulo, 1960.

ALVARO DE OLIVEIRA, Carlos Alberto. Do Formalismo no Processo Civil: proposta de um formalismo-valorativo. 3. ed. São Paulo: Saraiva, 2009.

Efetividade e processo de conhecimento. Cadernos do Programa de Pós-Graduação em Direito - PPGDir./UFRGS, v. 2, n. 4. Porto Alegre, 2014. Disponível em http://seer.ufrgs.br/index.php/ppgdir/article/view/49206/30837.

O formalismo-valorativo no confronto com o formalismo excessivo, in Leituras Complementares de Processo Civil. Org. Fredie Didier Jr. 6. ed. Salvador: JusPodivm, 2008. . Teoria e Prática da Tutela Jurisdicional. Rio de Janeiro: Forense, 2008.

ALVIM, Arruda. Manual de Direito Processual Civil: teoria geral do processo e processo de conhecimento. 17. ed. São Paulo: Editora Revista dos Tribunais, 2017.

_. Sentença 'citra petita' - necessidade de ação rescisória. Revista de Processo, n. 14. São Paulo: Revista dos Tribunais, 1979.

ALVIM, Teresa Arruda. Nulidades do processo e da sentença. 6. ed. São Paulo: Revista dos Tribunais, 2007.

_. Omissão Judicial e Embargos de Declaração. São Paulo: Revista dos Tribunais, 2005.

Precedentes e evolução do direito, in Direito Jurisprudencial. Coord. Teresa Arruda Alvim. São Paulo: Revista dos Tribunais, 2012.

AMARAL, Francisco. Direito Civil: introdução. 6. ed. Rio de Janeiro: Renovar, 2006. 
AMARAL, Paulo Osternack. Provas: atipicidade, liberdade e instrumentalidade. 2. ed. São Paulo: Revista dos Tribunais, 2017.

AMERICANO, Jorge. Comentários ao Código de Processo Civil do Brasil, v. 4. 2. ed. São Paulo: Saraiva, 1960.

APRIGLIANO, Ricardo. Ordem Pública e Processo: o tratamento das questões de ordem pública no Direito Processual Civil. São Paulo: Atlas, 2011.

ARAGÃO, Egas Dirceu Moniz de. Comentários ao Código de Processo Civil, v. II. Rio de Janeiro: Forense, 1974.

. Sentença e Coisa Julgada: exegese do Código de Processo Civil (art. 444 a 475).

Rio de Janeiro: Aide, 1992.

ARENHART, Sérgio Cruz. A verdade e a prova no processo civil. Disponível em https://www.academia.edu/214442/A_VERDADE_E_A_PROVA_NO_PROCESSO_CIVI L.

- Reflexões sobre o princípio da demanda. Disponível em https://www.academia.edu/221841/Reflex\%C3\%B5es_sobre_o_princ\%C3\%ADpio_da_de manda.

; MARINONI, Luiz Guilherme. Processo de Conhecimento. 7. ed. São Paulo: Revista dos Tribunais, 2008.

; MARINONI, Luiz Guilherme; MITIDIERO, Daniel. Novo Curso de Processo Civil: teoria do processo civil, v.1. 3. ed. São Paulo: Revista dos Tribunais, 2017.

; MARINONI, Luiz Guilherme; MITIDIERO, Daniel. Novo Curso de Processo Civil: tutela dos direitos mediante procedimento comum, v. 2. 2. ed. São Paulo: Revista dos Tribunais, 2016.

; MARINONI, Luiz Guilherme. Procedimentos Especiais. 4. ed. São Paulo: Revista dos Tribunais, 2013.

ASCARELLI, Tullio. Inesistenza e nullità. Rivista di Diritto Processuale, XI. Padova: Cedam, 1956.

ASSIS, Araken de. Cumulação de Ações. 4. ed. São Paulo: Revista dos Tribunais, 2002. . Manual dos Recursos. 2. ed. São Paulo: Revista dos Tribunais, 2008. . Processo Civil Brasileiro, v. I, 2. ed. São Paulo: Editora Revista dos Tribunais, 2016. 
Processo Civil Brasileiro, v. II, tt. I e II. São Paulo: Editora Revista dos Tribunais, 2015.

. Processo Civil Brasileiro, v. III. 2. São Paulo: Editora Revista dos Tribunais, 2016. AUILO, Rafael Stefanini. O Modelo Cooperativo de Processo Civil no Novo CPC. Salvador: JusPodivm, 2017.

ÁVILA, Humberto B. O que é 'devido processo legal'? Revista de Processo, n. 163. São Paulo: Revista dos Tribunais, 2008.

. Repensando o "Princípio da Supremacia do Interesse Público sobre o Particular",

in Interesses Públicos Versus Interesses Privados: Desconstruindo o Princípio da Supremacia do Interesse Público. Rio de Janeiro: Lumen Juris, 2007.

Teoria dos Princípios: da definição à aplicação dos princípios jurídicos. 11. ed. São Paulo: Malheiros, 2010.

AZEVEDO, Antônio Junqueira de. Negócio Jurídico: existência, validade e eficácia. 4. ed. São Paulo: Saraiva, 2010.

AZEVEDO, Luiz Carlos de; TUCCI, José Rogério Cruz e. Lições de História do Processo Civil Romano. São Paulo: Revista dos Tribunais, 2001.

BANDEIRA DE MELlO, Celso Antônio. Curso de Direito Administrativo. 25. ed. São Paulo: Malheiros, 2008.

BARBI, Celso Agrícola. Comentários ao Código de Processo Civil, v. I, tt. I e II. Rio de Janeiro: Forense, 1975.

BARBOSA MOREIRA, José Carlos. Comentários ao Código de Processo Civil, v. V. Rio de Janeiro: Forense, 1974.

. O neoprivatismo no processo civil. Revista de Processo, n. 122. São Paulo: Revista dos Tribunais, 2005.

. O Novo Processo Civil Brasileiro: exposição sistemática do procedimento. 27. ed. Rio de Janeiro: Forense, 2008.

BARREIROS, Lorena Miranda Santos. Fundamentos constitucionais do princípio da cooperação processual. Salvador: JusPodvm, 2013. 
BARRIÈRE, Louis-Augustin. Une approche historique de la summa divisio droit publicdroit privé, in De L'Intérêt de la Summa Divisio Droit Public-Droit Privé? Coord. Baptiste Bonnet e Pascale Deumier. Paris: Dalloz, 2010.

BARS, Thierry Le; HÉRON, Jacques. Droit Judiciaire Privé. 6. ed. Paris: LGDJ, 2015.

BAUR, Fritz. Da importância da diç̧ão 'iura novit curia'. Revista de Processo, n. 3. São Paulo: Revista dos Tribunais, 1976.

BEDAQUE, José Roberto dos Santos. Comentários ao art. 487, in Breves Comentários ao Novo Código de Processo Civil. Coord. Teresa Arruda Alvim, Fredie Didier Jr., Eduardo Talamini e Bruno Dantas. São Paulo: Revista dos Tribunais, 2015.

Efetividade do Processo e Técnica Processual. São Paulo: Malheiros, 2006.

. Instrumentalismo e garantismo: visões opostas do fenômeno processual?, in Garantismo Processul: garantias constitucionais aplicadas ao processo. Brasília: Gazeta Jurídica, 2016.

. Os elementos objetivos da demanda examinados à luz do contraditório, in Causa de pedir e pedido no processo civil: (questões polêmicas). Coord. José Rogério Cruz e Tucci, José Roberto dos Santos Bedaque. São Paulo: Revista dos Tribunais, 2002.

Poderes Instrutórios do Juiz. 4. ed. São Paulo: Revista dos Tribunais, 2009.

BELL, John. Le débat au Royaume-Uni, in Le Contrôle Juridictionnel de l'Administration. Paris: Economica, 1991.

BENEDUZI, Renato. Introdução ao Processo Civil Alemão. Salvador: JusPodivm, 2015.

BERMANN, George A. Le débat aux États-Unis, in Le Contrôle Juridictionnel de l’Administration. Paris: Economica, 1991.

BESSO, Chiara. La Sentenza Civile Inesistente. Torino: G. Giappichelli, 1996.

BOMFIM, Daniela Santos. A legitimidade extraordinária de origem negocial, in Negócios Processuais. Coord. Antonio do Passo Cabral, Pedro Henrique Nogueira. Salvador: JusPodvm, 2015.

BONDIOLI, Luis Guilherme Aidar. Comentário ao art. 322, in Breves Comentários ao Novo Código de Processo Civil. Coord. Teresa Arruda Alvim, Fredie Didier Jr., Eduardo Talamini e Bruno Dantas. São Paulo: Revista dos Tribunais, 2015. 
BONNET, Baptiste. La summa divisio droit public-droit privé, chimère ou pierre angulaire?, in De L'Intérêt de la Summa Divisio Droit Public-Droit Privé? Coord. Baptiste Bonnet e Pascale Deumier. Paris: Dalloz, 2010.

; DEUMIER, Pascale. Avant-propos, in De L'Intérêt de la Summa Divisio Droit Public-Droit Privé? Coord. Baptiste Bonnet e Pascale Deumier. Paris: Dalloz, 2010.

BOUDOT, Michel. L'enseignement du droit, un instrument de la summa divisio?, in De L'Intérêt de la Summa Divisio Droit Public-Droit Privé? Coord. Baptiste Bonnet e Pascale Deumier. Paris: Dalloz, 2010.

BRAGA, Paula Sarno; DIDIER JR., Fredie; OLIVEIRA, Rafael Alexandria de. Curso de Direito Processual Civil, v. 2. 10. ed. Salvador: JusPodvm, 2015.

BRONIEWICZ, Witold. I poteri del giudice in rapporto ai poteri delle parti nel processo civile polacco. Rivista di Diritto Processuale, n. XXXIV, 3. Padova: CEDAM, 1979.

BUENO, Cassio Scarpinella. Manual de Direito Processual Civil. 3. ed. São Paulo: Saraiva, 2017.

BÜLOW, Oskar von. La Teoría de las Excepciones Procesales y los Presupuestos Procesales. Buenos Aires: Ed. Juridicas Europa - America, 1964.

CABRAL, Antonio do Passo. A resolução $n^{\circ} 118$ do Conselho Nacional do Ministério Público e as convenções processuais, in Negócios Processuais. Coord. Antonio do Passo Cabral, Pedro Henrique Nogueira. Salvador: JusPodvm, 2015.

, Antonio do Passo. Convenções Processuais. Salvador: JusPodivm, 2016.

CABRAL, Trícia Navarro Xavier. Poderes Instrutórios do Juiz no Processo de Conhecimento. Brasília: Gazeta Jurídica, 2012.

. Reflexos das convenções em matéria processual nos atos judiciais, in Negócios Processuais. Coord. Antonio do Passo Cabral, Pedro Henrique Nogueira. Salvador: JusPodvm, 2015.

CADIET, Loïc. Les conventions relatives au procès en droit français. Sur la contractualisation du règlement des litiges. Rivista Trimestrale di Diritto e Procedura Civile, numero speciale: Accordi di Parte e Processo. Milano: Giuffrè, 2008.

; JEULAND, Emmanuel. Droit Judiciarie Privé. 8. ed. Paris: LexisNexis, 2013.

; NORMAND, Jacques; MEKKI, Soraya Amrani. Théorie Générale du Procès. 2. ed. Paris: PUF, 2013. 
CAENEGEM, R. C. Van. An Historical Introduction to Private Law. Trad. D. E. L Johnston. Cambridge: Cambridge University Press, 1992.

CALAMANDREI, Piero. Abolizione del Processo Civile?, in Opere Giuridiche, v. VI. Org. Mauro Cappelletti. Napoli: Morano, 1976.

_. Il concetto di "lite" nel pensiero di Francesco Carnelutti, in Opere Giuridiche, v. I. Org. Mauro Cappelletti. Napoli: Morano, 1965.

_. La Cassazione Civile, v. I, in Opere Giuridiche, v. VI. Org. Mauro Cappelletti. Napoli: Morano, 1976.

La sentenza soggetivamente complessa, in Opere Giuridiche, v. I. Org. Mauro Cappelletti. Napoli: Morano, 1965.

. Linee fondamentali del processo civile inquisitorio, in Opere Giuridiche, v. I. Org. Mauro Cappelletti. Napoli: Morano, 1965.

. Processo e Democrazia, in Opere Giuridiche, v. I. Org. Mauro Cappelletti. Napoli: Morano, 1965.

CALMES, Sylvia. Du Principe de Protection de la Confiance Légitime en Droits Allemand, Communautaire et Français. Paris: Dalloz, 2001.

CÂMARA, Alexandre Freitas. Lições de Direito Processual Civil, v. 1. 9. ed. Rio de Janeiro: LumenJuris, 2004.

CALMON DE PASSOS, José Joaquim. Comentários ao Código de Processo Civil, v. III. Rio de Janeiro: Forense, s.d.

CAMBI, Eduardo. A Prova Civil: admissibilidade e relevância. São Paulo: Revista dos Tribunais, 2006.

CAMPOS, Francisco. O Estado Nacional. Brasília: Senado Federal, 2001.

CAPONE, Arturo. Iura Novit Curia: studio sulla riqualificazione giuridica del fatto nel processo penale. Padova: CEDAM, 2010.

CAPONI, Remo. Autonomia privata e processo civile: gli accordi processuali. Rivista Trimestrale di Diritto e Procedura Civile, numero speciale: Accordi di Parte e Processo. Milano: Giuffrè, 2008.

CAPORAL, Stéphane. La summa divisio des facultés, in De L'Intérêt de la Summa Divisio Droit Public-Droit Privé? Coord. Baptiste Bonnet e Pascale Deumier. Paris: Dalloz, 2010. 
CAPPELLETTI, Mauro. Aspectos sociais e políticos do processo civil, in Processo, Ideologias e Sociedade, v. 1. Trad. Elício de Cresci Sobrinho. Porto Alegre: Sergio Antonio Fabris Editor, 2008.

. El Testimonio de la Parte en el Sistema de la Oralidad, vv. 1 e 2. Trad. Tomás A. Banzhaf. La Plata: Librería Editora Platense, 2002.

CARNACINI, Tito. Tutela giurisdizionale e tecnica del processo, in Studi in Onore di Enrico Redenti nel XL anno del suo insegnamento, v. 2. Milano: Giuffrè, 1951.

CARNEIRO, Athos Gusmão. Intervenção de Terceiros. 18. ed. São Paulo: Saraiva, 2009.

Do cumprimento de sentença conforme a Lei 11.232/2005. Parcial retorno ao medievalismo? Por que não? Revista da AJURIS, n. 102. Rio Grande do Sul, 2006.

CARNELUTTI, Francesco. Eccezione e analisi dell'esperienza. Rivista di Diritto Processuale, v. XV. Padova: CEDAM, 1960.

. Istituzioni del Nuovo Processo Civile Italiano, t. I. 3.ed. Roma: Foro Italiano, 1942.

. La Prova Civile. 2. ed. Roma: Edizioni Dell'Ateneo, 1947.

. Sistema del Diritto Processuale Civile, v.1. Padova: CEDAM, 1936.

_. Un lapsus evidente? Rivista di Diritto Processuale, v. XV. Padova: CEDAM, 1960.

CARRATTA, Antonio. Funzione sociale e processo civile fra XX e XXI secolo. Disponível em http://romatrepress.uniroma3.it/ojs/index.php/funzione/article/view/506.

_. Poteri del Giudice. Coautoria com Michele Taruffo. Org. Sergio Chiarloni. Bologna: Zanichelli, 2015.

; MANDRIOLI, Crisanto. Corso di Diritto Processuale Civile, v. I. 13. ed. Torino: G. Giappichelli, 2016.

CASTRO, Gonçalo Andrade e; XAVIER, Rita Lobo; FOLHADELA, Inês. Elementos de Direito Processual Civil. Porto: Universidade Católica, 2014.

CAVALLINI, Cesare. Iura novit curia (civil law e common law). Rivista di Diritto Processuale, n. LXXII, 3. Milano: Giuffrè, 2017.

CAVALLONE, Bruno. I poteri di iniziativa istruttoria del giudice civile. Premessa storicocritica, in Il Giudice e la Prova nel Processo Civile. Padova: CEDAM, 1997. 
Alessandro Giuliani Processualista (ordine isonomico, ordine asimmetrico, principio dispositivo, principio inquisitorio). Rivista di Diritto Processuale, n. LXVII, 1. Milano: CEDAM, 2012.

, Bruno. In difesa della veriphobia (considerazioni amichevolmente polemiche su un livro di Michele Taruffo). Rivista di Diritto Processuale, n. LXV, 1. Milano: CEDAM, 2010. CAZETTA JÚNIOR, José Jesus. Conteúdo da causa de pedir e proposta de aplicação dessa categoria ao recurso extraordinário: um exame crítico, in Causa de pedir e pedido no processo civil: (questões polêmicas). Coord. José Rogério Cruz e Tucci, José Roberto dos Santos Bedaque. São Paulo: Revista dos Tribunais, 2002.

CHAGAS, Bárbara Seccato Ruis; MAZZEI, Rodrigo. Os negócios jurídicos processuais e a arbitragem, in Negócios Processuais. Coord. Antonio do Passo Cabral, Pedro Henrique Nogueira. Salvador: JusPodvm, 2015.

CHAINAIS, Cécile; GUINCHARD, Serge; FERRAND, Frédérique. Procédure Civile. Droit interne et droit de l'Union européenne. 32. ed. Paris: Dalloz, 2014.

CHEV ALLIER, Jacques. L'État Post-Moderne. 3. ed. Paris: L.G.D.J, 2008.

CHIARLONI, Sergio. Sulla rilevabilità in sede di gravame della nullità ex art. 101, comma $2^{o}$, c.p.c. Rivista Trimestrale di Diritto e Procedura Civile, n. LXV. Numero speciale: la disponibilità della tutela giurisdizionale (cinquant'anni doppo). Giuffrè: Varese, 2011.

CHIOVENDA, Giuseppe. Adolfo Wach, in Saggi di Diritto Processuale Civile, v. I. Milano: Giuffrè, 1993.

. Del sistema negli studi del processo civile, in Saggi di Diritto Processuale Civile, v. I. Milano: Giuffrè, 1993.

. Della condanna nelle spese a favore del procuratore, in Saggi di Diritto Processuale Civile, v. III. Milano: Giuffrè, 1993.

Identificazione delle azioni. Sulla regola `ne eat iudex ultra petita partium , in Saggi di Diritto Processuale Civile, v. I. Milano: Giuffrè, 1993.

L'azione nel sistema dei diritti, in Saggi di Diritto Processuale Civile, v. I. Milano: Giuffrè, 1993.

La pubblica amministrazione e la condanna nelle spese davanti la IV sezione del Consiglio di Stato, in Saggi di Diritto Processuale Civile, v. III. Milano: Giuffrè, 1993. 
Le forme nella defesa giudiziale del diritto, in Saggi di Diritto Processuale Civile, v. I. Milano: Giuffrè, 1993.

. Le spese del processo civile romano, in Saggi di Diritto Processuale Civile, v. III. Milano: Giuffrè, 1993.

_. Le riforme processual e le correnti del pensiero moderno, in Saggi di Diritto Processuale Civile, v. I. Milano: Giuffrè, 1993.

. Lo stato attuale del processo civile in Italia ed il progetto Orlando di riforme processuali, in Saggi di Diritto Processuale Civile, v. I. Milano: Giuffrè, 1993.

. Principii di Diritto Processuale Civile. Reimp. Napoli: Jovene, 1965

Romanesimo e germanesimo nel processo civile, in Saggi di Diritto Processuale Civile, v. I. Milano: Giuffrè, 1993.

CHIZZINI, Augusto. Contraddittorio, principio dispositivo e poteri del giudice nelle trasformazioni del diritto processuale civile, in Pensiero e azione nella storia del processo civile. Studi. 2. ed. Milano: Utet Giuridica, 2014.

_. Franz Klein, la codificazione sociale e la procedura civile in Italia, in Pensiero e azione nella storia del processo civile. Studi. 2. ed. Milano: Utet Giuridica, 2014.

In dubio pro libertate. Note sul pensiero giuridico di Edoardo Garbagnati, in Pensiero e azione nella storia del processo civile. Studi. 2. ed. Milano: Utet Giuridica, 2014. Oralità e dimensione retorica nella genesi del processo civile, in Pensiero e azione nella storia del processo civile. Studi. 2. ed. Milano: Utet Giuridica, 2014.

CHRÉTIEN, Patrice; GUÉDON, Marie-José; DUPUIS, Georges. Droit Administratif. 10. ed. Paris: Dalloz, 2007.

CIANCI, Mirna; MEGNA, Bruno Lopes. Fazenda Pública e negócios jurídicos processuais no novo CPC: pontos de partida para o estudo, in Negócios Processuais. Coord. Antonio do Passo Cabral, Pedro Henrique Nogueira. Salvador: JusPodvm, 2015.

CINTRA, Antonio Carlos de Araújo; GRINOVER, Ada Pellegrini; DINAMARCO, Cândido Rangel. Teoria Geral do Processo. 13. ed. São Paulo: Malheiros, 1997.

CIPRIANI, Franco. I problemi del processo di cognizione tra passato e presente, in Il Processo Civile nello Stato Democratico. Napoli: Edizioni Scientifiche Italiane, 2010. 
Il processo civile nello Stato democratico, in Il Processo Civile nello Stato Democratico. Napoli: Edizioni Scientifiche Italiane, 2010.

. Il processo civile tra vecchie ideologie e nuovi slogan, in Il Processo Civile nello Stato Democratico. Napoli: Edizioni Scientifiche Italiane, 2010.

. Le dimissioni del Professore Mortara e i "Germanisti" del Preside Scialoja. Rivista di Diritto Processuale, n. 3. Milano: CEDAM, 1990.

Code Louis, t. 1. Ordonnance Civile, 1667, in Testi e Documenti per la Storia del Processo, v. I. Org. Nicola Picardi e Alessandro Giuliani. Milano: Giuffrè, 1996.

Codice di Procedura Civile della Repubblica Socialista Federativa Sovietica di Russia, in Testi e Documenti per la Storia del Processo, v. IX. Org. Nicola Picardi e Alessandro Giuliani. Milano: Giuffrè, 2004.

COELHO, Inocêncio Mártires. Curso de Direito Constitucional. 4. ed. Coautoria com Gilmar Ferreira Mendes e Paulo Gustavo Gonet Branco. São Paulo: Saraiva, 2009.

COLOMER, Juan Luiz Gómez; MONTERO AROCA, Juan; VILAR, Silvia Barona. Derecho Jurisdiccional I: parte general. 24. ed. Valencia: Tirant lo Blanch, 2016.

; MONTERO AROCA, Juan; VILAR, Silvia Barona; CUADRADO, María Pia Calderón. Derecho Jurisdiccional II: Proceso Civil. 24. ed. Valencia: Tirant lo Blanch, 2016. COMOGLIO, Luigi Paolo; FERRI, Corrado; TARUFFO, Michele. Lezioni sul Processo Civile. I. Il processo ordinario di cognizione. Bologna: il Mulino, 1995.

CONSOLO, Claudio. Il duplice volto della "buona" giustizia civile tardo-asburgica e del suo rigeneratore, in Testi e Documenti per la Storia del Processo, v. VIII. Org. Nicola Picardi e Alessandro Giuliani. Milano: Giuffrè, 2004.

CORDERO, Franco. Guida alla Procedura Penale. Torino: UTET, 1986.

_. Procedura Penale. 3.ed. Milano: Giuffrè, 1995.

COSTA, Moacyr Lobo da. A Revogação da Sentença: gênese e genealogia. São Paulo: Ícone, 1995.

COUTINHO, Jacinto Nelson de Miranda. O papel do novo juiz no processo penal, in Crítica à Teoria Geral do Direito Processual Penal. Coord. Jacinto Nelson de Miranda Coutinho. Rio de Janeiro: Renovar, 2001. 
COUTURE, Eduardo J. Fundamentos del Derecho Procesal Civil. 4. ed. Montevideo: BdeF, 2010.

. Inconstitucionalidad por privación de la garantía del debido proceso, in Estudios de Derecho Procesal Civil, t. I. 3. ed. Buenos Aires: Depalma, 2003.

CUADRADO, María Pia Calderón; MONTERO AROCA, Juan; COLOMER, Juan Luis Gómez; VILAR, Silvia Barona. Derecho Jurisdiccional II: Proceso Civil. 24. ed. Valencia: Tirant lo Blanch, 2016.

CUNHA, Leonardo José Carneiro da. Anotações sobre a desistência da ação, disponível em http://www.abdpc.org.br/abdpc/artigos/Leonardo\%20Jos\%C3\%A9\%20Carneiro\%20da\%2 0Cunha\%20-\%20formatado.pdf.

. Comentário ao art. 493, in Breves Comentários ao Novo Código de Processo Civil. Coord. Teresa Arruda Alvim, Fredie Didier Jr., Eduardo Talamini e Bruno Dantas. São Paulo: Revista dos Tribunais, 2015.

. Negócios jurídicos processuais no processo civil brasileiro, in Negócios Processuais.

Coord. Antonio do Passo Cabral, Pedro Henrique Nogueira. Salvador: JusPodvm, 2015.

; DIDIER JR., Fredie. Curso de Direito Processual Civil, v. 3. 13. ed. Salvador: JusPodivm, 2016.

; DIDIER JR., Fredie. Curso de Direito Processual Civil, v. 3. 3. ed. Salvador: JusPodivm, 2007.

DAVID, René; JAUFFRET-SPINOSI, Camille. Les Grands Systèmes de Droit Contemporains. 11. ed. Paris: Dalloz, 2002.

DAWSON, John P. The Oracles of the Law. New York: William S. Hein, 1986.

DELFINO, Lúcio; NUNES, Dierle José Coelho. Enunciado da Enfam mostra juízes contra o contraditório no novo CPC. Disponível em https://www.conjur.com.br/2015-set03/enunciado-enfam-mostra-juizes-contraditorio-cpc.

DEUMIER, Pascale ; BONNET, Baptiste. Avant-propos, in De L'Intérêt de la Summa Divisio Droit Public-Droit Privé? Coord. Baptiste Bonnet e Pascale Deumier. Paris: Dalloz, 2010.

DI PIETRO, Maria Sylvia Zanella. Direito Administrativo. 20. ed. São Paulo: Atlas, 2007. DIDIER JR., Fredie. Curso de Direito Processual Civil, v. 1. Salvador: JusPodivm, 2007. 
. Fonte normativa da legitimação extraordinária no novo Código de Processo Civil: a legitimação extraordinária de origem negocial. Disponível em: https://www.academia.edu/8541198/Fonte_normativa_da_legitima\%C3\%A7\%C3\%A3o_e xtraordin\%C3\%A1ria_a_legitima\%C3\%A7\%C3\%A3o_extraordin\%C3\%A1ria_negocial.

_. Os três modelos de direito processual: inquisitivo, dispositivo e cooperativo. Disponível em https://www.academia.edu/1771108/Os_tr\%C3\%AAs_modelos_de_direito_processual. . Curso de Direito Processual Civil, v. 1. 17. ed. Salvador: JusPodivm, 2015.

; BRAGA, Paula Sarno; OLIVEIRA, Rafael Alexandria de. Curso de Direito Processual Civil, v. 2. 10. ed. Salvador: JusPodvm, 2015.

; CUNHA, Leonardo Carneiro da. Curso de Direito Processual Civil, v. 3. 3. ed. Salvador: JusPodivm, 2007.

; CUNHA, Leonardo Carneiro da. Curso de Direito Processual Civil, v. 3. 13. ed. Salvador: JusPodivm, 2016.

_. Princípio do respeito ao autorregramento da vontade no processo civil, in Negócios Processuais. Coord. Antonio do Passo Cabral, Pedro Henrique Nogueira. Salvador: JusPodvm, 2015.

DINAMARCO, Cândido Rangel. A Instrumentalidade do Processo. 12. ed. São Paulo: Malheiros, 2005.

_. Execução Civil. 8. ed. São Paulo: Malheiros, 2002.

_. Instituições de Direito Processual Civil, v. I. 4. ed. São Paulo: Malheiros, 2004.

_. Instituições de Direito Processual Civil, v. II. 5. ed. São Paulo: Malheiros, 2005.

_. Instituições de Direito Processual Civil, v. III. 5. ed. São Paulo: Malheiros, 2005.

—. O conceito de mérito em processo civil. Revista de Processo, n. 34. São Paulo: Revista dos Tribunais, 1984.

_. O princípio do contraditório e sua dupla destinação, in Fundamentos do Processo Civil Moderno, v. I. 6. ed. São Paulo: Malheiros, 2010.

_. Polêmicas do processo civil: Windscheid e Muther, in Fundamentos do Processo Civil Moderno, v. I. 6. ed. São Paulo: Malheiros, 2010. 
Tutela jurisdicional, in Fundamentos do Processo Civil Moderno, v. I. 6. ed. São Paulo: Malheiros, 2010.

; CINTRA, Antonio Carlos de Araújo; GRINOVER, Ada Pellegrini. Teoria Geral do Processo. 13. ed. São Paulo: Malheiros, 1997.

DONIZETTI, Elpídio. Curso didático de direito processual civil, 17 ed. São Paulo: Atlas. 2013.

DÓRIA, Antônio Roberto Sampaio. Direito Constitucional Tributário e "Due Process of Law”. 2. ed. Rio de Janeiro: Forense, 1986.

DUPUIS, Georges; GUÉDON, Marie-José; CHRÉTIEN, Patrice. Droit Administratif. 10. ed. Paris: Dalloz, 2007.

EID, Elie Pierre. Litisconsórcio Unitário: fundamentos, estrutura e regime. São Paulo: Editora Revista dos Tribunais, 2016.

ENGELMANN, Arthur. The Mediaeval German Procedure, in History of Continental Civil Procedure, v. VII. Org. Arthur Engelmann. Trad. Robert. Wyness Millar. Boston: Little, Brown, and Company, 1927.

. The Roman Procedure, in A History of Continental Civil Procedure, v. VII. Org. Arthur Engelmann. Trad. Robert. Wyness Millar. Boston: Little, Brown, and Company, 1927.

The romano-canonical procedure, in History of Continental Civil Procedure, v. VII. Org. Arthur Engelmann. Trad. Robert. Wyness Millar. Boston: Little, Brown, and Company, 1927.

FABIANI, Ernesto. I Poteri Istruttori del Giudice Civile: contributo al chiarimento del dibattito. Napoli: Edizione Scientifiche Italiane, 2008.

FABRÍCIO, Adroaldo Furtado. Comentários ao Código de Processo Civil, v. VIII. Rio de Janeiro: Forense, 1980.

_. Extinção do Processo e Mérito da Causa. Revista de Processo, n. 58. São Paulo: Revista dos Tribunais, 1990.

FARIA, Guilherme Henrique Lage. Negócios Processuais no Modelo Constitucional de Processo. Salvador: JusPodivm, 2016. 
FASCHING, Walter Hans. Liberalización y socialización del proceso civil. Trad. Raúl Nocedal M. Boletín Mexicano de Derecho Comparado, n. 13-14. Disponível em https://revistas.juridicas.unam.mx/index.php/derecho-comparado/article/view/891/1151.

FERRAND, Frédérique; GUINCHARD, Serge; CHAINAIS, Cécile. Procédure Civile. Droit interne et droit de l'Union européenne. 32. ed. Paris: Dalloz, 2014.

FERRAZ JR., Tercio Sampaio. As origens do Estado contemporâneo ou o Leviathan gestor da economia, in Direito Constitucional. Barueri: Manole, 2007.

FERRI, Corrado; COMOGLIO, Luigi Paolo; TARUFFO, Michele. Lezioni sul Processo Civile. I. Il processo ordinario di cognizione. Bologna: il Mulino, 1995.

FOLHADELA, Inês; XAVIER, Rita Lobo; CASTRO, Gonçalo Andrade e. Elementos de Direito Processual Civil. Porto: Universidade Católica, 2014.

FONSECA, Priscila M. P. Corrêa da. Dissolução Parcial, Retirada e Exclusão de Sócio no Novo Código Civil. 2. ed. São Paulo: Atlas, 2003.

FOURNIER, Marcel; SCHULTE, Frédéric; GLASER, William A. Précis Théorique et Pratique de Procédure Civile. Paris: Pichon, 1902. Versão digital disponibilizada por Archive.org.

FRANÇA, Erasmo Valladão Azevedo e Novaes; ADAMEK, Marcelo Vieira von. Da Ação de Dissolução Parcial de Sociedade: comentários breves ao CPC/2015. São Paulo: Malheiros, 2016.

FREITAS, José Lebre de. A Confissão no Direito Probatório: um estudo de direito positivo. 2. ed. Coimbra: Coimbra Editora, 2013.

FROMONT, Michel. Le débat à l'étranger, in Le Contrôle Juridictionnel de l'Administration. Paris: Economica, 1991.

FURNO, Carlo. Nullità e rinnovazione degli atti processuali. in Studi in Onore di Enrico Redenti nel XL anno del suo insegnamento, v. 1. Milano: Giuffrè, 1951.

GANUZAS, Francisco Javier Exquiaga. Iura Novit Curia y Aplicación Judicial del Derecho. Madrid: Lex Nova, 2000.

GLASER, William A. Pretrial Discovery and the Adversary System. New York: Russel Sage Foundation, 1968. 
GLASSON, Ernest. Histoire du Droit et des Institutions de la France, t. III. Paris: F. Pichon, 1889. Versão digital disponibilizada por BnF Gallica. . Histoire du Droit et des Institutions de L'Allemagne.

; SCHULTE, Frédéric; FOURNIER, Marcel. Précis Théorique et Pratique de Procédure Civile. Paris: Pichon, 1902. Versão digital disponibilizada por Archive.org.

GOLDSCHMIDT, James. Derecho Procesal Civil. 2. ed. Trad. Leonardo Prieto Castro. Barcelona: Labor, 1936.

GOMES, Orlando. Contratos. 26. ed. Rio de Janeiro: Forense, 2007.

GRECO, Leonardo. Os atos de disposição processual - primeiras reflexões, in Os Poderes do Juiz e o Controle das Decisões Judiciais: estudos em homenagem à Professora Teresa Arruda Alvim Wambier. Coord. José Miguel Garcia Medina e outros. São Paulo: Revista dos Tribunais, 2008.

. Publicismo e privatismo no processo civil. Revista de Processo, n. 164. São Paulo: Revista dos Tribunais, 2008.

GRECO FILHO, Vicente. Direito Processual Civil Brasileiro, v. 2. 12. ed. São Paulo: Saraiva, 1997.

GRINOVER, Ada Pellegrini; DINAMARCO, Cândido Rangel; CINTRA, Antonio Carlos de Araújo. Teoria Geral do Processo. 13. ed. São Paulo: Malheiros, 1997.

GUÉDON, Marie-José; DUPUIS, Georges; CHRÉTIEN, Patrice. Droit Administratif. 10. ed. Paris: Dalloz, 2007.

GUINCHARD, Serge; CHAINAIS, Cécile; FERRAND, Frédérique. Procédure Civile. Droit interne et droit de l'Union européenne. 32. ed. Paris: Dalloz, 2014.

GURVIC, Mark. A. Profili generali del processo civile sovietico, in Codice di Procedura Civile della Repubblica Socialista Federativa Sovietica di Russia, in Testi e Documenti per la Storia del Processo, v. IX. Org. Nicola Picardi e Alessandro Giuliani. Milano: Giuffrè, 2004.

HACHEM, Daniel Wunder. Princípio Constitucional da Supremacia do Interesse Público. Belo Horizonte: Fórum, 2011.

HAYEK, F. A. The Constitution of Liberty: the definitive edition. Ed. Ronald Hamowy. Chicago: The University of Chicago, 2011. 
HAZARD JR., Geoffrey C.; TARUFFO, Michele. American Civil procedure. An introduction. New Haven: Yale University Press, 1993.

HÉRON, Jacques; BARS, Thierry Le. Droit Judiciaire Privé. 6. ed. Paris: LGDJ, 2015.

JACKSON, Jeffrey D. Putting rationality back into the rational basis test: saving substantive due process and redeeming the promise of the Ninth Amendment. University of Richmond Law Review, v. 45, n. 2, 2011.

JAUERNIG, Othmar. Direito Processual Civil. 25. ed. Trad. F. Silveira Ramos. Coimbra: Almedina, 2002.

JEULAND, Emmanuel; CADIET, Loïc. Droit Judiciarie Privé. 8. ed. Paris: LexisNexis, 2013.

JOLOWICZ, John A. On Civil Procedure. New York: Cambridge University Press, 2000.

JORGE, Flávio Cheim. Teoria Geral dos Recursos Cíveis. 3. ed. São Paulo: Revista dos Tribunais, 2007.

JUNOY, Joan Picó Y. El derecho procesal entre el garantismo y la eficacia: un debate mal planteado, in Processo Civil e Ideología. 2. ed. Coord. Juan Montero Aroca. Valencia: Tirant lo Blanch, 2011.

JUSTEN FILHO, Marçal. Curso de Direito Administrativo. 2. ed. São Paulo: Saraiva, 2006. Curso de Direito Administrativo. 12. ed. São Paulo: Revista dos Tribunais, 2016.

KAGAN, Robert A. Adversarial Legalism: the American way of law. Cambridge: Harvard University Press, 2003

KELLNER, Horst. Introduzione, in Ordinanza della Procedura Civile della Repubblica Democratica Tedesca, in Testi e Documenti per la Storia del Processo, v. X. Org. Nicola Picardi e Alessandro Giuliani. Milano: Giuffrè, 2004.

KERN, Christoph A. Procedural contracts in Germany, in Negócios Processuais. Coord. Antonio do Passo Cabral, Pedro Henrique Nogueira. Salvador: JusPodvm, 2015.

KESSLER, Amalia D. Inventing American Exceptionalism: the origins of American adversarial legal culture, 1800-1877. New Haven: Yale University Press, 2017

KOHLER, Christian. L'Autonomie de la Volonté en Droit International Privé: un principe universel entre libéralisme et étatisme. Maubeuge : ADI, 2013. 
KOZIKOSKI, Sandro Marcelo. Sistema Recursal CPC 2015: em conformidade com a Lei 13.256/2016. Salvador: JusPodvm, 2016.

LANTIERI, Rossella Lavinia; PICARDI, Nicola. La giustizia civile in Russi da Pietro il Grande a Krusciev Codice di Procedura Civile della Repubblica Socialista Federativa Sovietica di Russia, in Testi e Documenti per la Storia del Processo, v. IX. Org. Nicola Picardi e Alessandro Giuliani. Milano: Giuffrè, 2004.

LEONEL, Ricardo de Barros. Objeto litigioso do processo e o princípio do duplo grau de jurisdição, in Causa de pedir e pedido no processo civil: (questões polêmicas). Coord. José Rogério Cruz e Tucci, José Roberto dos Santos Bedaque. São Paulo: Revista dos Tribunais, 2002.

LIEBMAN, Enrico Tullio. Eficácia e Autoridade da Sentença: e outros escritos sobre a coisa julgada. Trad. Alfredo Buzaid e Benvindo Aires. Rio de Janeiro: Forense, 1945. . Il fondamento del principio dispositivo, in Problemi del Processo Civile. Napoli: Morano, 1962.

_. Il nuovo 'Código de Processo Civil' brasiliano, in Problemi del Processo Civile. Napoli: Morano, 1962.

Istituti del diritto commune nel processo civile brasiliano, in Problemi del Processo Civil. Milano: Morano, 1962. . Manual de Direito Processual Civil, v. 1. 3. ed. Trad. Cândido Rangel Dinamarco. São Paulo: Malheiros, 2005.

. O Despacho Saneador e o Julgamento do Mérito, in Estudos sobre o Processo Civil Brasileiro. Ipiranga: Bestbook, 2004.

_. Processo de Execução. 5. ed. São Paulo: Saraiva, 1986.

_. Sul riconoscimento della domanda, in Problemi del Processo Civile. Napoli: Morano, 1962.

LIPIANI, Júlia; SIQUEIRA, Marília. Negócios jurídicos processuais sobre a fase recursal, in Negócios Processuais. Coord. Antonio do Passo Cabral, Pedro Henrique Nogueira. Salvador: JusPodvm, 2015.

LOPES, Bruno Vasconcelos Carrilho. Limites Objetivos e Eficácia Preclusiva da Coisa Julgada. São Paulo: Saraiva, 2012. 
LUISO, Francesco P. Poteri di ufficio del giudice e contradditorio. Rivista Trimestrale di Diritto e Procedura Civile, n. LXV. Numero speciale: la disponibilità della tutela giurisdizionale (cinquant'anni doppo). Giuffrè: Varese, 2011.

MACHADO, António Montalvão. O Dispositivo e os Poderes do Tribunal à Luz do Novo Código de Processo Civil. 2. ed. Coimbra: Livraria Almedina, 2001.

MACHADO, Marcelo Pacheco. A Correlação no Processo Civil: relações entre demanda e tutela jurisdicional. Salvador: JusPodvm, 2015.

MALIN, Mauro. Campos, Francisco, in Dicionário Histórico-Biográfico Brasileiro - Pós1930. Coord. Alzira Alves de Abreu e outros Disponível em: http://cpdoc.fgv.br/sites/default/files/verbetes/primeirarepublica/CAMPOS,\%20Francisco.pdf.

MANDRIOLI, Crisanto; CARRATTA, Antonio. Corso di Diritto Processuale Civile, v. I. 13. ed. Torino: G. Giappichelli, 2016.

MARCATO, Antonio Carlos. Procedimentos Especiais. 10. ed. São Paulo: Atlas, 2004.

MARINONI, Luiz Guilherme. Teoria Geral do Processo. São Paulo: Revista dos Tribunais, 2006.

; ARENHART, Sérgio Cruz. Processo de Conhecimento. 7. ed. São Paulo: Revista dos Tribunais, 2008.

; ARENHART, Sérgio Cruz; MITIDIERO, Daniel. Novo Curso de Processo Civil: teoria do processo civil, v.1. 3. ed. São Paulo: Revista dos Tribunais, 2017.

; ARENHART, Sérgio Cruz; MITIDIERO, Daniel. Novo Curso de Processo Civil: tutela dos direitos mediante procedimento comum, v. 2. 2. ed. São Paulo: Revista dos Tribunais, 2016.

; ARENHART, Sérgio Cruz. Procedimentos Especiais. 4. ed. São Paulo: Revista dos Tribunais, 2013.

MAZZEI, Rodrigo; CHAGAS, Bárbara Seccato Ruis. Os negócios jurídicos processuais e a arbitragem, in Negócios Processuais. Coord. Antonio do Passo Cabral, Pedro Henrique Nogueira. Salvador: JusPodvm, 2015. 
MEGNA, Bruno Lopes; CIANCI, Mirna. Fazenda Pública e negócios jurídicos processuais no novo CPC: pontos de partida para o estudo, in Negócios Processuais. Coord. Antonio do Passo Cabral, Pedro Henrique Nogueira. Salvador: JusPodvm, 2015.

MEKKI, Soraya Amrani; CADIET, Loïc; NORMAND, Jacques. Théorie Générale du Procès. 2. ed. Paris: PUF, 2013.

; STRICKLER, Yves. Procédure Civile. Paris: PUF, 2014.

MELENDO, Santiago Sentís. El Juez y el Derecho: iura novit curia. Buenos Aires: E. J. E. A., 1957.

MELlO, Marcos Bernardes de. Teoria do Fato Jurídico: plano da existência. 16. ed. São Paulo: Saraiva, 2010.

MENDONÇA, Luís Correia de. 80 anos de autoritarismo: uma leitura política do processo civil português, in Processo Civil e Ideología. 2. ed. Coord. Juan Montero Aroca. Valencia: Tirant lo Blanch, 2011.

MENGER, Anton. Il Diritto Civile e il proletariato: studio critico sul progetto di un codice civile per l'impero germanico. Trad. Giuseppe Oberosler. Torino: Fratelli Boca, 1894.

L'Etat Socialiste. Trad. Edgar Milhaud. Paris: Georges Bellais, 1904.

METZGER, Ernest. Litigation in Roman Law. Oxford: Oxford University Press, 2005.

MICHELI, Gian Antonio. Derecho Procesal Civil, v. I. Trad. Santiago Sentís Melendo. Buenos Aires: Ediciones Jurídicas Europa-América, 1970.

Derecho Procesal Civil, v. II. Trad. Santiago Sentís Melendo. Buenos Aires: Ediciones Jurídicas Europa-América, 1970.

. Jura novit curia, in Derecho Procesal Civil, v. IV. Trad. Santiago Sentís Melendo. Buenos Aires: Ediciones Jurídicas Europa-América, 1970.

. Rinuncia alla pretesa e riconoscimento della pretesa nella dottrina italiana. Rivista di Diritto Processuale, n. 1. Padova: Giuffrè, 1937.

MILLAR, Robert Wyness. Germany and Austria - Chapter III. The Reforms of 1924, in A History of Continental Civil Procedure, v. VII. Org. Arthur Engelmann. Trad. Robert. Wyness Millar. Boston: Little, Brown, and Company, 1927. 
. The formative principles of civil procedure, in A History of Continental Civil Procedure, v. VII. Org. Arthur Engelmann. Trad. Robert. Wyness Millar. Boston: Little, Brown, and Company, 1927.

MITIDIERO, Daniel; MARINONI, Luiz Guilherme; ARENHART, Sérgio Cruz. Novo Curso de Processo Civil: tutela dos direitos mediante procedimento comum, v. 2. 2. ed. São Paulo: Revista dos Tribunais, 2016.

; MARINONI, Luiz Guilherme; ARENHART, Sérgio Cruz. Novo Curso de Processo Civil: teoria do processo civil, v.1. 3. ed. São Paulo: Revista dos Tribunais, 2017.

MONTEIRO, Marta. Jura novit curia in international commercial arbitration. Dissertação de Mestrado. Universidade de Helsinki, 2013.

MONTELEONE, Girolamo. Manuale di Diritto Processuale Civile, v. I. Padova: Cedam, 2012.

. Princípios e ideologias del processo civil: impressiones de un 'revisionista', in Processo Civil e Ideología. 2. ed. Coord. Juan Montero Aroca. Valencia: Tirant lo Blanch, 2011.

MONTERO AROCA, Juan. El processo civil llamado 'social' como instrumento de 'justicia' autoritária, in Processo Civil e Ideología. 2. ed. Coord. Juan Montero Aroca. Valencia: Tirant lo Blanch, 2011.

. Sobre el mito autoritario de la "buena fe procesal", in Processo Civil e Ideología.

2. ed. Coord. Juan Montero Aroca. Valencia: Tirant lo Blanch, 2011.

; COLOMER, Juan Luiz Gómez; VILAR, Silvia Barona. Derecho Jurisdiccional I: parte general. 24. ed. Valencia: Tirant lo Blanch, 2016.

; COLOMER, Juan Luis Gómez; VILAR, Silvia Barona; CUADRADO, María Pia Calderón. Derecho Jurisdiccional II: Proceso Civil. 24. ed. Valencia: Tirant lo Blanch, 2016. MONTESANO, Luigi. La garanzia costituzionale del contradittorio e $i$ giudizi civile di 'terza via'. Rivista di Diritto Processuale. Milano: CEDAM, 2000.

MONTORO, André Franco. Introdução à Ciência do Direito. 31. ed. São Paulo: Revista dos Tribunais, 2014.

MORTARA, Lodovico. Istituzioni di Ordinamento Giudiziario. Firenze: G. Barbèra, 1906. 
. Manuale della Procedura Civile, v. 1. 5. ed. Torino: Unione Tipografico-Editrice, 1906.

. Principii di Procedura Civile. Firenze: G. Barbèra, 1890.

MORTON, J. Alex. Civil Procedure in the U.S.S.R. Case Western Reserve Journal of International Law, n. 7, 1975.

MOTULSKY, Henri. Direito Privado. Hermenêutica e Realização Metódica. A teoria dos Elementos Geradores dos Direitos Subjetivos. Trad. Márcia Atálla Pietroluongo. Rio de Janeiro: Forense, 2014.

La cause de la demande dans la délimitation de l'office juge in Écrits: Études et notes de procédure civile. Paris: Dalloz, 2010.

La réforme du Code de procédure civile par le décret du 13 octobre 1965 et les principes directeurs du procès, in Écrits: Études et notes de procédure civile. Paris: Dalloz, 2010.

Le rôle respectif du juge et des parties dans l'allégation des faits, in Écrits: Études et notes de procédure civile. Paris: Dalloz, 2010.

. Les rapports entre l'effet dévolutif de l'appel et l'évocation dans la jurisprudence récente de la Cour Suprême, in Écrits: Études et notes de procédure civile. Paris: Dalloz, 2010.

. Prolégomènes pour un futur Code de procédure civile: la consécration des principes directeurs du procès civil par le décret du 9 septembre 1971, in Écrits: Études et notes de procédure civile. Paris: Dalloz, 2010.

MUTHER, Theodor. Sulla dottrina dell'actio romana, in Polemica intorno all'actio di Windscheid e Muther. Trad. Ernst Heinitz e Giovanni Pugliese. Firenze: Sansoni, 1954.

NASI, Antonio. Disposizione del Diritto e Azione Dispositiva. Milano: Giuffrè, 1965.

NEGRÃO, Theotonio et alii. Código de Processo Civil e Legislação Processual em Vigor, 45. ed. São Paulo: Saraiva, 2013.

NERY, Rosa Maria de Andrade; NERY JUNIOR, Nelson. Código de Processo Civil Comentado e Legislação Extravagante. São Paulo: Revista dos Tribunais, 2010.

NERY JUNIOR, Nelson; NERY, Rosa Maria de Andrade. Código de Processo Civil Comentado e Legislação Extravagante. São Paulo: Revista dos Tribunais, 2010. 
Teoria Geral dos Recursos. 7. ed. São Paulo: Revista dos Tribunais, 2014.

NOGUEIRA, Pedro Henrique. Negócios Jurídicos Processuais. Salvador: JusPodivm, 2016. - Sobre os acordos de procedimento no processo civil brasileiro. in Negócios Processuais. Coord. Antonio do Passo Cabral, Pedro Henrique Nogueira. Salvador: JusPodvm, 2015.

NORMAND, Jacques; CADIET, Loïc; MEKKI, Soraya Amrani. Théorie Générale du Procès. 2. ed. Paris: PUF, 2013.

NOVA, Giorgio di. Accordi delle parti e decisione. Rivista Trimestrale di Diritto e Procedura Civile, numero speciale: Accordi di Parte e Processo. Milano: Giuffrè, 2008.

NUNES, Dierle José Coelho. Processo Jurisdicional Democrático: uma análise crítica das reformas processuais. Curitiba: Juruá, 2008.

; DELFINO, Lúcio. Enunciado da Enfam mostra juízes contra o contraditório no novo CPC. Disponível em https://www.conjur.com.br/2015-set-03/enunciado-enfam-mostrajuizes-contraditorio-cpc.

Ordinanza della Procedura Civil di Francesco Giuseppe (1895), in Testi e Documenti per la Storia del Processo, v. VIII. Org. Nicola Picardi e Alessandro Giuliani. Milano: Giuffrè, 2004.

Ordinanza della Procedura Civile della Repubblica Democratica Tedesca, in Testi e Documenti per la Storia del Processo, v. X. Org. Nicola Picardi e Alessandro Giuliani. Milano: Giuffrè, 2004.

Ordinanza della Procedura Civile dell'Impero Germanico (1877/1898), in Testi e Documenti per la Storia del Processo, v. VI. Org. Nicola Picardi e Alessandro Giuliani. Milano: Giuffrè, 2002.

OLIVEIRA, Paulo Mendes de. Negócios processuais e o duplo grau de jurisdição, in Negócios Processuais. Coord. Antonio do Passo Cabral, Pedro Henrique Nogueira. Salvador: JusPodvm, 2015.

OLIVEIRA, Rafael Alexandria de; DIDIER JR., Fredie; BRAGA, Paula Sarno. Curso de Direito Processual Civil, v. 2. 10. ed. Salvador: JusPodvm, 2015.

PAULSEN, Michael Stokes. Does the constitution prescribe rules for its own interpretation? Northwestern University Law Review, n. 8, 2009. 
PENADÉS, Rafael Bellido; RAMOS, Manuel Ortells. La demanda. La contestación y otras alegaciones, in Derecho Procesal Civil. 15. ed. Navarra: Aranzadi, 2016.

PEREIRA, Guilherme Setoguti J. Verdade e finalidade da prova. Revista de Processo, n. 213. São Paulo: Revista dos Tribunais, 2012.

PETRONIO, Ugo. Introduzione. Il futuro ha un cuore antico. Considerazioni sul Codice di Procedura Civile del 1806, in Testi e Documenti per la Storia del Processo, v. V. Org. Nicola Picardi e Alessandro Giuliani. Milano: Giuffrè, 2000.

PIAZZON, Thomas. La Sécurité Juridique. Paris: Defrénois, 2009.

PICARDI, Nicola. Dal giudizio al processo, in La Giurisdizione all'Alba del Terzo Millennio. Milano: Giuffrè, 2007.

. Do juízo ao processo, in Jurisdição e Processo. Trad. Carlos Alberto Alvaro de Oliveira. Rio de Janeiro: Forense, 2008.

. Giurisdizione e sovranità, in La Giurisdizione all'Alba del Terzo Millennio. Milano: Giuffrè, 2007.

_. Il monopolio statuale della giurisdizione e della procedura, in La Giurisdizione all'Alba del Terzo Millennio. Milano: Giuffrè, 2007.

_La giurisdizione nel diritto comune, in La Giurisdizione all'Alba del Terzo Millennio. Milano: Giuffrè, 2007.

. Le riforme processuali e sociali di Franz Klein. Historia et ius, n. 2, 2012. Disponível em http://www.historiaetius.eu/uploads/5/9/4/8/5948821/picardi2.pdf.

. Prefazione, in Ordinanza della Procedura Civile della Repubblica Democratica Tedesca, in Testi e Documenti per la Storia del Processo, v. X. Org. Nicola Picardi e Alessandro Giuliani. Milano: Giuffrè, 2004.

; LANTIERI, Rossella Lavinia. La giustizia civile in Russi da Pietro il Grande a Krusciev Codice di Procedura Civile della Repubblica Socialista Federativa Sovietica di Russia, in Testi e Documenti per la Storia del Processo, v. IX. Org. Nicola Picardi e Alessandro Giuliani. Milano: Giuffrè, 2004.

PITA, Maria Paula Díaz. Derecho Procesal Civil, t. I. Madrid : Tecnos, 2016.

PONCET, M. Traité des Jugements Précédé du Traité des Actions. Bruxelles : Librairie de Jurisprudence de H. Tarlier, 1835. Disponível em Google Livros. 
PONTES DE MIRANDA, Francisco Cavalcanti. Comentários ao Código de Processo Civil, t. II. Rio de Janeiro: Forense, 1973. . Comentários ao Código de Processo Civil, t. IV. Rio de Janeiro: Forense, 1974. . Comentários ao Código de Processo Civil, t. V. Rio de Janeiro: Forense, 1974. . Comentários ao Código de Processo Civil, t. VI. Rio de Janeiro: Forense, 1975. . Comentários ao Código de Processo Civil, t. VII. Rio de Janeiro: Forense, 1975.

_. Tratado de Direto Privado, t. VI. 4. ed. São Paulo: Revista dos Tribunais, 1983.

_. Tratado de Direito Privado, t. XXV. 3. ed. São Paulo: Revista dos Tribunais, 1984. PUGLIATTI, Salvatore. Autonomia privata, in Enciclopedia del Diritto, v. IV. Milano: Giuffrè, 1959.

PUGLIESE, Giovanni. Giudicato Civile (storia), in Enciclopedia del Diritto, v. XVIII. Varese: Giuffrè, 1969.

. Introduzione, in Polemica intorno all'actio di Windscheid e Muther. Firenze: Sansoni, 1954.

PUNZI, Carmine; SATTA, Salvatore. Diritto Processuale Civile. 13. ed. Padova: Cedam, 2006.

RAATZ, Igor. Autonomia Privada e Processo Civil. Salvador: JusPodivm, 2017

RADBRUCH, Gustav. La securité en droit d'après la théorie anglaise. Archives de Philosophie du Droit e de Sociologie Juridique, n. 3-4. Paris: Sirey, 1936.

RAIMBAULT, Philippe. Recherche sur la Sécurité Juridique en Droit Administratif Français. Paris: L.G.D.J, 2009.

RAMINA DE LUCCA, Rodrigo. Iura novit curia nas arbitragens. Revista Brasileira de Arbitragem, v. 13. São Paulo: Revista dos Tribunais, 2016.

Julgamentos antecipados parciais do mérito. Revista de Processo, n. 257. São Paulo: Revista dos Tribunais, 2016. . O Dever de Motivação das Decisões Judiciais: Estado de Direito, segurança jurídica e teoria dos precedentes. 2. ed. Salvador: JusPodvm, 2016. . O mérito do processo e as condições da ação. Revista de Processo, n. 188. São Paulo: Revista dos Tribunais, 2010. 
Os limites objetivos da coisa julgada no novo Código de Processo Civil. Revista de Processo, n. 252. São Paulo: Revista dos Tribunais, 2016.

Querela nullitatis e réu revel não citado no processo civil brasileiro. Revista de Processo, 202. São Paulo: Revista dos Tribunais, 2011.

RAMOS, Elival da Silva. Ativismo Judicial: parâmetros dogmáticos. São Paulo: Saraiva, 2010 .

RAMOS, Manuel Ortells. Derecho Procesal Civil. 15. ed. Navarra: Aranzadi, 2016.

; PENADÉS, Rafael Bellido. La demanda. La contestación y otras alegaciones, in Derecho Procesal Civil. 15. ed. Navarra: Aranzadi, 2016.

RAZ, Joseph. The Rule of Law and its virtue, in The Authority of Law: essays on law and morality. New York: Oxford University, 2002.

RECHBERGER, Walter H.; KODEK, Georg. E. Introduzioni: l'Ordinanza della Procedura Civile austriaca del 1895.

REDENTI, Enrico. Diritto Processuale Civile, v. II. 2. ed. Milano: Giuffrè, 1957.

REDONDO, Bruno Garcia. Negócios processuais: necessidade de rompimento radical com o sistema do CPC/1973 para a adequada compreensão da inovação do CPC/2015, in Negócios Processuais. Coord. Antonio do Passo Cabral, Pedro Henrique Nogueira. Salvador: JusPodvm, 2015.

RHEE, C. H. Van. Introduction, in European Traditions in Civil Procedure. Org. C.H. van Rhee. S.L. Intersentia, 2005.

RICCI, Edoardo F. Il principio dispositivo come problema di diritto vigente. Rivista di Diritto Processuale Civile. Padova: CEDAM, 1974.

ROCCO, Alfredo. La Sentencia Civil. México - Distrito Federal: Tribunal Superior de Justicia del Distrito Federal - MEX, 2003.

RODRIGUES, Fernando Pereira. O Novo Processo Civil. Os Princípios Estruturantes. Coimbra: Almedina, 2013.

ROSENBERG, Leo. Tratado de Derecho Procesal Civil, t. I. Trad. Angela Romera Vera. Buenos Aires: Ediciones Jurídicas Europa-América, 1955.

. Tratado de Derecho Procesal Civil, t. II. Trad. Angela Romera Vera. Buenos Aires: Ediciones Jurídicas Europa-América, 1955. 
ROUBIER, Paul. Droit Subjectifs et Situations Juridiques. Paris: Dalloz, 2005. . Théorie Générale du Droit. 2. ed. Paris: Sirey, 1951.

ROUSSEAU, Dominique. Juger, une profession et un acte citoyen. Revue Projet, n. 323. S.1.: CERAS, 2011.

SALVIOLI, Giuseppe. Manuale di Storia del Diritto Italiano dalle Invasioni Germaniche ai Nostri Giorni. Torino: Unione tipografico-editrice, 1890.

SÁNCHEZ, Guillermo Ormazabal. Iura Novit Curia: la vinculación del juez a la calificación jurídica de la demanda. Madrid: Marcial Pons, 2007.

SANTOS, Moacyr Amaral. Comentários ao Código de Processo Civil, t. IV. Rio de Janeiro: Forense, 1976.

Da Reconvenção no Direito Brasileiro. 4. ed. São Paulo: Max Limonad, 1973. . Primeiras Linhas de Direito Processual Civil, v. 2. 19. ed. São Paulo: Saraiva, 1998.

SANTOS, Marco Antonio Cabral dos. Francisco Campos: um ideólogo para o Estado Novo. Locus: Revista de História, v. 13, n. 2. Juiz de Fora: UFJF, 2007.

SARMENTO, Daniel. Os princípios constitucionais da liberdade e da autonomia privada. Boletim Científico: Escola Superior do Ministério Público da União, n. 14. Brasília, 2005. Disponível em http://boletimcientifico.escola.mpu.mp.br/boletins/boletim-cientifico-n.-142013-janeiro-marco-de-2005/os-principios-constitucionais-da-liberdade-e-da-autonomiaprivada.

Dignidade da Pessoa Humana na Ordem Constitucional Brasileira: conteúdo, trajetórias e metodologia. Tese de Titularidade, Faculdade de Direito, Universidade do Estado do Rio de Janeiro, Rio de Janeiro, 2015.

SATTA, Salvatore. Dalla procedura civile al diritto processuale civile, in Soliloqui e Colloqui di un Giurista. Reimp. Nuoro: Ilisso, 2004.

. Gli orientamenti pubblicistici della scienza del processo (con postilla), in Soliloqui e Colloqui di un Giurista. Reimp. Nuoro: Ilisso, 2004.

_. Iura novit curia. Rivista Trimestrale di Diritto e Procedura Civile. Milano: Giuffrè, 1955.

Orientamenti e disorientamenti nella scienza del processo, in Soliloqui e Colloqui di un Giurista. Reimp. Nuoro: Ilisso, 2004. 
Storia e "publicizzazione" nel processo (con postilla), in Soliloqui e Colloqui di un Giurista. Reimp. Nuoro: Ilisso, 2004.

; PUNZI, Carmine. Diritto Processuale Civile. 13. ed. Padova: Cedam, 2006.

SAVIGNY, M.F.C. de. Traité de Droit Romain, t. I. Trad. M. Ch. Guenoux. Paris: Firmin Didot Frères, 1855. Versão digital disponibilizada por BnF Gallica.

SCHÖNKE, Adolf. Derecho Procesal Civil. 5. ed. Trad. Prieto Castro. Barcelona: Bosch, 1950.

SCHULTE, Frédéric de; FOURNIER, Marcel; GLASSON, M. Ernest. Précis Théorique et Pratique de Procédure Civile. Paris: Pichon, 1902. Versão digital disponibilizada por Archive.org.

SCHWAB, Karl Heinz. El Objeto Litigioso en el Proceso Civil. Trad. Tomás A. Banzhaf. Buenos Aires: E.J.E.A., 1968.

SCHWARTZ, Johann Christoph. Germany and Austria. Chapter I. The later development in Austria, in A History of Continental Civil Procedure. Org. Arthur Engelmann. Trad. Robert. Wyness Millar. Boston: Little, Brown, and Company, 1927.

Germany and Austria. Chapter II. The Code of 1895, in A History of Continental Civil Procedure. Org. Arthur Engelmann. Trad. Robert. Wyness Millar. Boston: Little, Brown, and Company, 1927.

SICA, Heitor Vitor Mendonça. O Direito de Defesa no Processo Civil Brasileiro: um estudo sobre a posição do réu. São Paulo: Atlas, 2011.

SILVA, Ovídio Araújo Baptista da. Curso de Processo Civil: processo de conhecimento, v.1. 7. ed. Rio de Janeiro: Forense, 2006.

. Limites objetivos da coisa julgada no direito brasileiro atual. Revista de Processo, n. 14-15. São Paulo: Revista dos Tribunais, 1979.

SILVA JR., Gervásio Lopes da. Julgamento Direito do Mérito na Instância Recursal (art. 515, $\left.\S 3^{\circ}, C P C\right)$. Salvador: JusPodivm, 2007.

SIQUEIRA, Marília; LIPIANI, Júlia. Negócios jurídicos processuais sobre a fase recursal, in Negócios Processuais. Coord. Antonio do Passo Cabral, Pedro Henrique Nogueira. Salvador: JusPodvm, 2015. 
SOUSA, Miguel Teixeira. Omissão do dever de cooperação: que consequências? Disponível em https://www.academia.edu/10210886/TEIXEIRA_DE_SOUSA_M._Omissão_do_dever_d e_cooperação_do_tribunal_que_consequências_01.2015_.

STRECK, Lênio. O que fazer quando juízes dizem que o novo CPC não deve ser obedecido? Disponível em: https://www.conjur.com.br/2015-jul-02/senso-incomum-quando-juizesdizem-ncpc-nao-obedecido.

STRICKLER, Yves; MEKKI, Soraya Amrani. Procédure Civile. Paris: PUF, 2014.

TALAMINI, Eduardo. Coisa Julgada e sua Revisão. São Paulo: Revista dos Tribunais, 2005.

; WAMBIER, Luiz Rodrigues. Curso Avançado de Processo Civil, v. 1. 16. ed. São Paulo: Revista dos Tribunais, 2016.

; WAMBIER, Luiz Rodrigues. Curso Avançado de Processo Civil, v. 2. 16. ed. São Paulo: Revista dos Tribunais, 2016.

; WAMBIER, Luiz Rodrigues. Curso Avançado de Processo Civil, v. 3. 12. ed. São Paulo: Revista dos Tribunais, 2013.

TARELLO, Giovanni. Il problema della riforma processuale in Italia nel primo quarto del secolo. Per uno studio della genesi dottrinale e ideologica del vigente codice italiano di procedura civil, in Dottrine del Processo Civile Studi Storici sulla Formazione del Diritto Processuale Civile. Bologna: il Mulino, 1989.

. L'opera di Giuseppe Chiovenda nel crepuscolo dello Stato liberale, in Dottrine del Processo Civile Studi Storici sulla Formazione del Diritto Processuale Civile. Bologna: il Mulino, 1989.

TARUFFO, Michele. La Prueba de los Hechos. Madri: Editorial Trotta, 2005.

. Poteri del Giudice. Coautoria com Antonio Carratta. Org. Sergio Chiarloni. Bologna: Zanichelli, 2015.

; COMOGLIO, Luigi Paolo; FERRI, Corrado. Lezioni sul Processo Civile. I. Il processo ordinario di cognizione. Bologna: il Mulino, 1995.

; HAZARD JR., Geoffrey C. American Civil procedure. An introduction. New Haven: Yale University Press, 1993. 
TELLES JUNIOR, Goffredo. Iniciação na Ciência do Direito. 4. ed. São Paulo: Saraiva, 2009.

THEODORO JR., Humberto, Curso de Direito Processual Civil, v. I. Rio de Janeiro: Forense, 2005.

. Curso de Direito Processual Civil: Procedimentos Especiais, v. III. 36. ed. Rio de Janeiro: Forense, 2006.

TUCCI, José Rogério Cruz e. A causa petendi no processo civil. 3. ed. São Paulo: Revista dos Tribunais, 2009.

. Reflexões sobre a cumulação subsidiária de pedidos, in Causa de pedir e pedido no processo civil: (questões polêmicas). Coord. José Rogério Cruz e Tucci, José Roberto dos Santos Bedaque. São Paulo: Revista dos Tribunais, 2002.

; AZEVEDO, Luiz Carlos de. Lições de História do Processo Civil Romano. 2. ed. São Paulo: Revista dos Tribunais, 2013.

VALEMBOIS, Anne-Laure. La Constitutionnalisation de l'Exigence de Sécurité Juridique en Droit Français. Paris: L.G.D.J, 2004.

VENOSA, Sílvio de Salvo. Direito Civil, v. II. 6. ed. São Paulo: Atlas, 2006.

VERDE, Giovanni. Considerazioni inattuali su giudicato e poteri del giudice. Rivista de Diritto Processuale, n. LXXII, 1. Milano: CEDAM, 2017.

VIANA, Juvêncio Vasconcelos. A causa de pedir nas ações de execução, in Causa de pedir e pedido no processo civil: (questões polêmicas). Coord. José Rogério Cruz e Tucci, José Roberto dos Santos Bedaque. São Paulo: Revista dos Tribunais, 2002.

VIGLIAR, José Marcelo Menezes. Pedido genérico e projeto de sentença, in Causa de pedir e pedido no processo civil: (questões polêmicas). Coord. José Rogério Cruz e Tucci, José Roberto dos Santos Bedaque. São Paulo: Revista dos Tribunais, 2002.

VILAR, Silvia Barona; COLOMER, Juan Luiz Gómez; MONTERO AROCA, Juan. Derecho Jurisdiccional I: parte general. 24. ed. Valencia: Tirant lo Blanch, 2016. ; COLOMER, Juan Luis Gómez; MONTERO AROCA, Juan; CUADRADO, María Pia Calderón. Derecho Jurisdiccional II: Proceso Civil. 24. ed. Valencia: Tirant lo Blanch, 2016. 
VINNIUS. Institutes de Justinien. Traité des Actions. Trad. L. J. Horace Degouy. J. B. Tixier de la Chapelle. Paris: Th. Barrois Père et Benjamin Duprat, 1830.

WACH, Adolf. Manual de Derecho Procesal Civil, v. I. Trad. Tomás A. Banzhaf. Buenos Aires: EJEA, 1977.

WAMBIER, Luiz Rodrigues; TALAMINI, Eduardo. Curso Avançado de Processo Civil, v. 1. 16. ed. São Paulo: Revista dos Tribunais, 2016.

; TALAMINI, Eduardo. Curso Avançado de Processo Civil, v. 2. 16. ed. São Paulo: Revista dos Tribunais, 2016.

; TALAMINI, Eduardo. Curso Avançado de Processo Civil, v. 3. 12. ed. São Paulo: Revista dos Tribunais, 2013.

WENGER, Leopold. Institutes of the Roman Law of Civil Procedure. Trad. Otis Harrison Fisk. Littleton: Fed B. Rothman \& Co., 1986.

WINDSCHEID, Bernhard. L" "actio" del diritto civile romano dal punto di vista del diritto odierno, in Polemica intorno all'actio di Windscheid e Muther. Trad. Ernst Heinitz e Giovanni Pugliese. Firenze: Sansoni, 1954.

WOLLSCHLÄGER, Christian. Introduzione. La Zivilprozzesordnung del 1877/1898, in Testi e Documenti per la Storia del Processo, v. VI. Org. Nicola Picardi e Alessandro Giuliani. Milano: Giuffrè, 2002.

XAVIER, Rita Lobo; FOLHADELA, Inês; CASTRO, Gonçalo Andrade e. Elementos de Direito Processual Civil. Porto: Universidade Católica, 2014.

YARSHELL, Flávio Luiz. Ação Rescisória: juízo rescindente e juízo rescisório no direito positivo brasileiro. Tese de Livre Docência, Faculdade de Direito, Universidade de São Paulo, São Paulo, 2004.

. Antecipação da prova sem o requisito da urgência e direito autônomo à prova. São Paulo: Malheiros, 2009.

Convenção das partes em matéria processual: rumo a uma nova era? in Negócios Processuais. Coord. Antonio do Passo Cabral, Pedro Henrique Nogueira. Salvador: JusPodvm, 2015.

. Curso de Direito Processual Civil, v. 1. São Paulo: Marcial Pons, 2014.

. Tutela Jurisdicional. 2. ed. São Paulo: DPJ, 2006. 
ZACLIS, Lionel. Cumulação eventual de pedidos e a jurisprudência do Superior Tribunal de Justiça, in Causa de pedir e pedido no processo civil: (questões polêmicas). Coord. José Rogério Cruz e Tucci, José Roberto dos Santos Bedaque. São Paulo: Revista dos Tribunais, 2002.

ZANZUCCHI, Marco Tullio. Diritto Processuale Civile, t. I. 4. ed. Milano: Giuffrè, 1948. ZUCKERMAN, Adrian. On Civil Procedure: principles of practice. 2. ed. London: Sweet\&Maxwell, 2011. 